\title{
COMMENTS
}

\section{Brandenburg $v$. Ohio: A Speech Test For All Seasons?}

"Inquiry on the issue of advocacy of the unlawful overthrow of the government is a greedy camel; it does not easily take its leave."*

Brandenburg $v$. Ohio ${ }^{1}$ is the Supreme Court's most recent comprehensive attempt to define when the first amendment protects advocacy of ideas or action, and when it does not. In Brandenburg, the Court stated in a unanimous per curiam opinion that

the constitutional guarantees of free speech and free press do not permit a State to forbid or proscribe advocacy of the use of force or of law violation except where such advocacy is directed to inciting or producing imminent lawless action and is likely to incite or produce such action. ${ }^{2}$

The phrase "inciting or producing imminent lawless action" was a novel contribution to the language of the first amendment.

This speech formula was articulated in an unusual case. Brandenburg was a Ku Klux Klan leader. ${ }^{3}$ He telephoned a Cincinnati

* Konigsberg v. State Bar of California, 52 Cal. 2d 769, 776, 344 P.2d 777, 782 (1959) (Traynor, Acting C.J., dissenting), aff'd, 366 U.S. 36 (1961), quoted in Kalven \& Steffen, The Bar Admission Cases: An Unfinished Debate Between Justice Harlan and Justice Black, 21 LAW in Transition 155, 178 n.49 (1961).

' 395 U.S. 444 (1969) (per curiam). Justices Black and Douglas filed separate concurrences. Id. at 449 (Black, J., concurring); id. at 450 (Douglas, J., concurring); see note 35 infra.

2395 U.S. at 447.

3 There is some indication that the Court deliberately chose to articulate this test in a case involving the political Right, rather than Left. "During the 1968-1969 term the Court had accepted for consideration five cases involving State sedition and unlawful assembly laws. At the end of the term, in June 1969, it ordered four of these cases set down for reargument in the new term beginning the following October," but it decided Brandenburg. T. EMERSON, The SYSTEM OF FREEDOM OF EXPRESSION, 155-56 \& n.80 (1970). The protagonists in the four cases not decided were all Left-wingers of some variety: see University Comm. to End the War in Vietnam v. Gunn, 289 F. Supp. 469 (W.D. Tex. 1968), appeal dismissed, 399 U.S. 383 (1970); Samuels v. Mackell, 288 F. Supp. 348 (S.D.N.Y. 1968), aff'd, 401 U.S. 66 (1971); Harris v. Younger, 281 F. Supp. 507 (C.D. Cal. 1968), rev'd, 401 U.S. 37 (1971); Landry v. Daley, 280 F. Supp. 938 (N.D. Ill. 1968), rev'd, 401 U.S. 77 (1971). When Brandenburg was decided in June 1969 the "movement" of the 1960s appeared to be at its 
television reporter and invited him to a Klan "rally" at a designated farm. When the reporter and a cameraman arrived, they found a handful of hooded figures, some armed; a wooden cross, later burned; and no audience "other than the participants and the newsmen who made the film." Brandenburg proceeded to make a vituperative speech that came closest to approaching advocacy of imminent lawless action in the passage:

We're not a revengent organization, but if our President, our Congress, our Supreme Court, continues to suppress the white, Caucasian race, it's possible that there might have to be some revengeance taken. ${ }^{5}$

Portions of this speech were filmed and subsequently shown on local and national television. The speech created no conceivable present danger. It was a pseudo-event, designed to exploit the media by generating free publicity. Nonetheless, an Ohio trial court sentenced Brandenburg to one to ten years under the Ohio Criminal Syndicalism Act, ${ }^{8}$ and the Ohio Court of Appeals and Supreme Court affirmed without opinions. ${ }^{\text {? }}$

The United States Supreme Court reversed the three lower courts, acquitting Brandenburg. The Court held that the Ohio

height: the street action at the 1968 Democratic Party convention was less than a year in the past, and the shootings at Kent State University were less than a year in the future. Two years later the Second Circuit Court of Appeals took judicial notice of "a nationwide campus atmosphere of ticking timebombs," Healy v. James, 445 F.2d 1122, 1132 n.39 (2d Cir. 1971), rev'd and remanded, 408 U.S. 169 (1972). It would not be surprising if the Court in announcing a more speech-protective test in so volatile a situation took care initially to apply it to the Right rather than the Left in order to demonstrate that it was expounding a "neutral" principle.

1 395 U.S. at $445-46$.

${ }^{5}$ Id. at 446.

- No person shall by word of mouth or writing advocate or teach the duty, necessity, or propriety of crime, sabotage, violence, or unlawful methods of terrorism as a means of accomplishing industrial or political reform . . . or organize or help to organize or become a member of, or voluntarily assemble with any society, group, or assemblage of persons formed to teach or advocate the doctrines of criminal syndicalism.

Whoever violates this section shall be fined not more than five thousand dollars or imprisoned not more than ten years, or both.

As used in [the above section] "criminal syndicalism" is the doctrine which advocates crime; sabotage, which is defined as the malicious injury or destruction of the property of another; violence; or unlawful methods of terrorism as a means of accomplishing industrial or political reform.

Act of April 15, 1919, 108 Laws of Ohio 189-90, repealed by Act of Dec. 14, 1972, § 2, 134 Laws of Ohio 2033.

7 The judge assigned to write the opinion for the Ohio Court of Appeals died before completing it. Brief for Appellant at 1, Brandenburg v. Ohio, 395 U.S. 444 (1969). The Ohio Supreme Court summarily dismissed defendant's appeal on the ground that it presented no substantial constitutional question. 395 U.S. at 445. 
Criminal Syndicalism Act was unconstitutionally overbroad on its face because it "purports to punish mere advocacy and to forbid, on pain of criminal punishment, assembly with others merely to advocate . . . " The Court explicitly overruled Whitney v. California, ${ }^{9}$ a 1927 decision upholding a statute nearly identical to the Ohio statute, thus rejecting Whitney's rationale that " 'advocating' violent means to effect political and economic change involves such danger to the security of the State that the State may outlaw it."10 Most important, the Court used Brandenburg to promulgate a new speech test, a test which protects all advocacy other than "incitement to imminent lawless action." 11

The significance of Brandenburg has not gone unnoticed. Professor Kalven described Brandenburg as a case in which the law of the first amendment "may finally have worked itself pure,"12 and the Brandenburg test has been praised by Gerald Gunther as a "coalescing of the best features" of previous speech tests. ${ }^{13}$ However, the current vitality of Brandenburg is in doubt. The Supreme Court, nearly as soon as it decided Brandenburg, began to undermine it by delineating a growing number of situations in which it need not be applied. The question of the current vitality of Brandenburg will form the focus of this comment.

This comment first examines the Brandenburg formula in light of the earlier Supreme Court cases and demonstrates how Brandenburg significantly increases the protection of advocacy. It then critically examines the instances in which the Court has divided over or been uncertain about Brandenburg's applicability. Finally, the comment argues that the concerns that moved some of the Justices to relax the Brandenburg requirements in those cases can be amply protected under Brandenburg itself.

\section{Content of the Brandenburg Test}

Prior to Brandenburg, the law concerning advocacy consisted of a series of variations on the doctrine of "clear and present danger" announced by Justice Oliver Wendell Holmes in Schenck $v$. United

395 U.S. at 449 .

- 274 U.S. 357 (1927).

10395 U.S. at 447.

"Id. at 449. This is the Court's own five-word summary of the full, fifty-word formulation earlier in the opinion, 395 U.S. at 447, quoted in text at note 2 supra.

12 Kalven, Professor Ernst Freund and Debs v. United States, 40 U. CHI. L. Rev. 235, 236 n.6 (1973).

13 Gunther, Learned Hand and the Origins of Modern First Amendment Doctrine: Some Fragments of History, 27 Stan. L. Rev. 719, 722 (1975). 
States. ${ }^{14}$ "The question in every case," Justice Holmes stated,

is whether the words used are used in such circumstances and are of such a nature as to create a clear and present danger that they will bring about the substantive evils that Congress has a right to prevent. ${ }^{15}$

The "clear and present danger" doctrine, uttered in response to Socialist opposition to American entry into World War I, was intended to explain why speech that was constitutionally protected in time of peace might be made criminal in time of war:

[T] he character of every act depends upon the circumstances in which it is done. . . . When a nation is at war many things that might be said in time of peace are such a hindrance to its effort that their utterance will not be endured so long as men fight . . . . ${ }^{16}$

Justice Holmes concluded that the pamphlet prepared by the petitioners in Schenck created a clear and present danger of obstruction of the draft and thus held that the petitioners' conviction for conspiring to distribute the pamphlet was constitutional. ${ }^{17}$

From the mid-1920s to the mid-1950s the most important decisions about advocacy concerned speech acts by Communists. These decisions highlighted two questions in particular: May the government punish a person for advocating illegal action to take place at some indefinite future time? And may the government punish abstract advocacy of (for instance) violent overthrow of the government? Supreme Court decisions during the early Cold War years answered the first question "yes," and the second question "no."

In Dennis $v$. United States, ${ }^{18}$ the Court reinterpreted the clear and present danger doctrine so that the danger which justifies government restriction of speech need not be "present" at all. The Court in Dennis upheld the constitutionality of certain provisions of the Smith Act, ${ }^{19}$ as well as convictions under the Act for conspiring to advocate and teach the desirability of overthrowing the government at some point in the future. In doing so, the Court held that the clear and present danger test requires a court to

" 249 U.S. 47 (1919).

15 Id. at 52 .

16 Id.

17 As a further illustration of unprotected speech, Justice Holmes offered the famous hypothetical of a person shouting "Fire" in a crowded theater. Id. He did not indicate whether the person had to know his or her cry was false in order for his or her speech to be unprotected.

18341 U.S. 494 (1951).

1918 U.S.C. § 2385 (1970). 
ask whether the gravity of the "evil," discounted by its improbability, justifies such invasion of free speech as is necessary to avoid the danger. ${ }^{20}$

In other words, the probability of the advocated danger occurring at some indefinite future time may be low, but if the gravity of the danger is great-and what could be more grave than the overthrow of the government? ${ }^{21}$ - then the speech may be curtailed. The Dennis version of the clear and present danger test thus permits broad speech restriction.

In Yates $v$. United States, ${ }^{22}$ however, the Court indicated that it could not live with the full implications of Dennis and held that mere advocacy of belief could not be made a crime. The Court reasoned that since the Smith Act was only aimed at prohibiting "the advocacy and teaching of concrete action for the forcible overthrow of the Government, and not of principles divorced from action," ${ }^{23}$ Dennis could not be read as obliterating the traditional distinction "between advocacy of abstract doctrine and advocacy of action." ${ }^{24}$ Advocacy of the principle of violent overthrow, the Court indicated, was protected by the first amendment, even if uttered with specific intent and hope to accomplish violent overthrow. ${ }^{25}$ Advocacy of "action for the accomplishment of forcible overthrow," on the other hand, was not protected, even if the action advocated was to take place at an indefinite future time:

The essential distinction is that those to whom the advocacy is addressed must be urged to do something, now or in the future, rather than merely to believe in something. ${ }^{28}$

The Court recognized that this distinction would often be "subtle and difficult to grasp," so it imposed strict evidentiary requirements upon the lower courts in order to ensure that speech would only be

341 U.S. at 510 (Vinson, C.J.), quoting Dennis v. United States, 183 F.2d 201, 212 (2d Cir. 1950) (L. Hand, J.). There were five opinions in the Supreme Court in Dennis, none of which mustered a majority. Justices Reed, Burton, and Minton joined Chief Justice Vinson's opinion to give it the most support of any. The Chief Justice adopted his version of the clear and present danger test from Judge Learned Hand's opinion below; Hand, in turn, had transferred to the law of the first amendment his recent tort law innovation, the so-called "Hand formula," United States v. Carroll Towing Co., 159 F.2d 169, 173 (2d Cir. 1947).

21 See note 134 infra.

2354 U.S. 298 (1957). Although the Yates Court technically only construed the Smith Act, it clearly sought to conform with the first amendment in doing so. See id. at 319-20.

2 Id. at 320.

24 Id.

${ }^{25}$ Id. at 321-22.

27. at 324-25. 
restricted in the "rare" case involving "advocacy of action."" 27

These safeguards notwithstanding, the composite doctrine that resulted from holding that advocacy of action at an indefinite future time was not protected, ${ }^{28}$ while advocacy of principles or abstract doctrine was protected, was unsatisfactory. In Dennis, the Court upheld the conviction of one group of Communist leaders for long prison terms because they had advocated the overthrow of the government as speedily as circumstances would permit. In Yates, different Communist leaders were acquitted because they had merely advocated the principle or abstract doctrine that violent overthrow was desirable. ${ }^{29}$ Yet the underlying speech activity in the cases was indistinguishable. The Communist agitation that the Court viewed as criminal incitement in 1951 was conceptualized as protected advocacy in 1957. The result was that a would-be speaker who either was not sufficiently versed in Supreme Court jurisprudence to recognize that Yates could be read as severely limiting Dennis, or who recognized that the lower courts could not be depended upon to read Dennis narrowly, had no way of predicting whether a court would categorize radical speech as criminal or protected. Such a speaker tended to keep silent. His or her speech was chilled.

The nub of the difficulty was that it is nearly impossible to distinguish advocacy of the abstract doctrine or belief that particular action is desirable from advocacy of action itself. Suppose a speaker says: "The government should be overthrown." Is this advocacy of belief or advocacy of action? If it is advocacy of belief, would it be converted into advocacy of action if the speaker were to say, in an emotional way, to an excited audience: "The government should be ovERTHRown!" If so, what is the critical variable that effects the transformation? Is it the intent inferred from the excited tone of voice? Is it the crowd's actual reaction? Or is it the crowd's rationally predictable reaction, regardless of how it actually reacted?

The Brandenburg opinion speaks to these issues, but somewhat cryptically, because it purports merely to summarize existing law. After stating the facts as noted above, ${ }^{30}$ the Court observed that its decision in Whitney $v$. California, upholding a statute similar to the

II Id. at 326-27.

23 See text and note at note 78 infra.

More precisely, the Yates appellants were acquitted because the instructions of the trial judge did not distinguish between advocacy of belief and advocacy of action, therefore the defendants might have been convicted for mereiy advocating principles or abstract doctrine. 354 U.S. at $312,327$.

so See text and notes at notes 4-7 supra. 
one under challenge, had been thoroughly discredited by its later decisions, such as Dennis. The Court then stated that these later decisions had fashioned the principle that advocacy of lawlessness could not be proscribed except where such advocacy

is directed to inciting or producing imminent lawless action and is likely to incite or produce such action. As we said in Noto v. United States, 367 U.S. 290, 297-98 (1961), "the mere abstract teaching . . . of the moral propriety or even moral necessity for a resort to force and violence, is not the same as preparing a group for violent action and steeling it to such action." [citations omitted]. A statute which fails to draw this distinction impermissibly intrudes upon the freedoms guaranteed by the First and Fourteenth Amendments. ${ }^{31}$

Although the opinion cited additional cases in its attempt to characterize the Brandenburg formulation as traditional law, the difficulty of its endeavor is illustrated by a footnote to the passage just quoted. The footnote which immediately follows the articulation of the advocacy test states:

It was on the theory that the Smith Act . . . embodied such a principle and that it had been applied only in conformity with it that this Court sustained the Act's constitutionality. [Dennis]. That this was the basis for Dennis was emphasized in [Yates], in which the Court overturned convictions for advocacy of the forcible overthrow of the government under the Smith Act, because the trial judge's instructions had allowed conviction for mere advocacy, unrelated to its tendency to produce forcible action. ${ }^{32}$

The footnote accurately summarizes the state of the law after Dennis and Yates. Those cases withdrew protection from speech which had a "tendency to produce forcible action" whether or not the state could show that the advocacy was directed to imminent action. Brandenburg, on the other hand, in the very text to which the footnote was appended, specifically required a showing of imminence before advocacy could be held to be unprotected. The footnote has caused some confusion. ${ }^{33}$

A second difficulty follows from the first. If Brandenburg

31395 U.S. at $447-48$.

32 Id. at $447 \mathrm{n} .2$ (emphasis added).

${ }^{33}$ See, e.g., In re Braverman, 271 Md. 196, 223-24, 316 A.2d 246, 259 (1974) (Smith, J., dissenting); cf. Hess v. State, 260 Ind. 427, 297 N.E.2d 413, rev'd, 414 U.S. 105 (1973), discussed in text and notes at notes 39-47 infra. 
merely restated Dennis and Yates, cases which purported to rely on the "clear and present danger" doctrine, then it is hard to understand the use of the phrase "imminent lawless action" in place of that well-known traditional formula. ${ }^{34}$ But if, on the other hand, Brandenburg went beyond Denniis and Yates, why did the Court not explain what it intended to accomplish by formulating a new test? In short, how is one to reconcile the Court's insistence that it is merely applying settled law with its creation of a new verbal formula, a formula that seems to be more speech-protective than the old tests?

On its face, Brandenburg does not resolve this ambiguity. The opinion never mentions the "clear and present danger" test and Justices Black and Douglas, in separate concurrences, attempt to read the decision as a rejection of that doctrine. ${ }^{35}$ Hence some commentators have concluded that Brandenburg substitutes "incitement" for "clear and present danger" as the appropriate primary concern of a court assessing political advocacy ${ }^{38}$ Other commenta-

${ }^{34}$ The phrase "imminent lawless action" perhaps originated in the declarations of Justices Holmes and Brandeis that political advocacy may be restricted only when it "produces or is intended to produce a clear and imminent danger." Abrams v. United States, 250 U.S. 616, 627 (1919) (Holmes, J., dissenting) (emphasis added); accord, Whitney v. California, 274 U.S. 357, 373 (1927) (Brandeis, J., concurring).

${ }^{35} 395$ U.S. at 450 (Black, J., concurring); id. at 450-57. (Douglas, J., concurring); see Filvaroff, Conspiracy and the First Amendment, 121 U. PA. L. Rev. 189, 238 n.171 (1972):

Whether or not Brandenburg should be read as revitalizing the "clear and present danger" test is another question. The concurring opinions of Justices Black and Douglas in Brandenburg are based on their assumption that the case does not have that consequence.

${ }^{36}$ E.g., EMERSon, supra note 3, at 157, 404, and Kalven, supra note 12. Those who favor an incitement test (as Professor Emerson does not: see EMERSon, supra note 3, at 75) believe that its promise lies in directing attention to the words actually used by the speaker, rather than to consequences which may not have been intended or predictable when the speech took place. In this view, Brandenburg belatedly adopts the test for determining whether advocacy is protected proposed during World War I by Judge Learned Hand: "If one stops short of urging upon others that it is their duty or their interest to resist the law . . . one should not be held to have attempted to cause its violation." Masses Publishing Co. v. Patten, 244 F. 535, 540 (S.D.N.Y.), rev'd, 246 F. 24 (2d Cir. 1917). There are two difficulties with this view. First, an "incitement" test, standing alone, is no more satisfactory than a "clear and present danger" test by itself. In his formulation of the incitement test, Judge Hand used the terms "advise," "counsel," "urge," "direct incitement," and "direct advocacy" interchangeably, and did not require that the action incited be present or imminent for the speech to be unprotected. 244 F. at 540-42. Justice Holmes understandably rejected Hand's incitement test as too vague, commenting that "[e]very idea is an incitement." Gitlow v. New York, 268 U.S. 652, 673 (1925). Moreover, given "today's fashions in incendiary rhetoric," Linde, "Clear and Present Danger" Reexamined: Dissonance in the Brandenburg Concerto, 22 STAN. L. REv. 1163, 1185 (1970), an incitement test might lead to conviction on the basis of choice of words alone, without an independent requirement that the state show an objective likelihood of imminent lawless action as a result of the speech. See Hutchin v. State, 290 So. 2d 35,38 (Fla. 1974) (Ervin, J., concurring): “A speaker's cry for warfare in the streets or to burn 
tors have come to a diametrically opposed conclusion. Rather than focus on the element of "incitement," these commentators emphasize the words "imminent lawless action" in the Brandenburg formulation. Viewing these words as surrogates for the phrase "clear and present danger," they find Brandenburg to be little more than a restatement of that traditional concept. ${ }^{37}$

Scrutiny of the Brandenburg opinion, however, suggests a third interpretation of its meaning: the importance of Brandenburg lies precisely in the fact that it is neither an incitement test, nor a clear and present danger test, but a combination of the two, requiring both elements before speech may be forbidden or proscribed. ${ }^{38}$ This interpretation is reinforced by recalling the state of the law of political advocacy when Brandenburg was decided. Under Schenck, Whitney, and other early cases, the state could restrict any kind of speech, including abstract advocacy, when it created a present danger. Under Dennis, Yates, and other post-World War II cases, abstract advocacy was protected, but incitement of lawless action was criminal whether the action was present or future. Brandenburg expressly overruled the abstract advocacy aspect of Whitney and affirmed in part the incitement aspect of Dennis-Yates. By implicitly repudiating the temporally-remote incitement notion of DennisYates and emphasizing imminence instead, Brandenburg had the novel effect of combining the Holmes-Brandeis insistence on present danger with the Dennis-Yates protection for abstract advocacy.

So read, Brandenburg's relation to previous political advocacy cases might be represented diagrammatically:

city hall which evokes only a response of laughter from his audience would not intrinsically amount to a criminal utterance."

Second, even if an incitement test were throught to be desirable, the Brandenburg test is something more. See text at note 38 infra. Yates, not Brandenburg, might be described as an incitement test. See Church, Conspiracy Doctrine and Speech Offenses: A Reexamination of Yates v. United States from the Perspective of United States v. Spock, 60 CoRNELL L. REv. 569, 578 (1975):

Probably the major accomplishment of the Yates court was its articulation of the elements of the crime of advocating violent revolution: "those to whom the advocacy is addressed must be urged to do something, now or in the future, rather than merely to believe in something." [354 U.S. at 324-25 (emphasis in original)]. The crime of advocacy of revolution must therefore consist of incitement to present or future violent acts.

${ }^{37}$ Liebmann, Chartering a National Police Force, 56 A.B.A.J. 1070, 1075 (1970); Strong, Fifty Years of "Clear and Present Danger": From Schenck To Brandenburg-And Beyond, 1969 Sup. CT. Rev. 41, 42; 39 U. Cin. L. Rev. 210, 211, 214 (1970); 72 W. VA. L. Rev. 117, 122 (1970).

3* Gunther, supra note 13 , and Linde, supra note 36 , essentially take this view of Brandenburg. 
Present or imminent danger

Incitement

Abstract or mere advocacy

2
Danger at some future time

Under Schenck, the state could restrict speech in situations 1 and 2 (any kind of speech which creates a present danger of evils the government has a right to prevent). Under Yates, the state could restrict speech in situations 1 and 3 (incitement of danger whether in the present or the future). Under Brandenburg, as here interpreted, the state could restrict speech only in situation 1 (incitement of present danger).

The Supreme Court, and a great many of the lower courts, have viewed Brandenburg in this third way, as requiring both incitement and a present, or imminent, danger. The key Supreme Court case is Hess $v$. Indiana ${ }^{39}$ in which Gregory Hess's conviction for disorderly conduct during the campus general strike at the time of the Cambodia invasion in May 1970 was overturned. There is some uncertainty concerning just what Hess said, and just how much of what he said was overheard by the arresting officers. ${ }^{40}$ It was stipulated before the Supreme Court of Indiana and of the United States that, as the police were clearing demonstrators from a street, Hess, "with his back to the police and facing the bulk of the demonstrators," said in a loud voice: "We'll take the fucking street later," or perhaps, "We'll take the fucking street again."

For both reviewing courts, the correctness of Hess's conviction depended squarely on what Brandenburg meant. The majority of the Indiana Supreme Court, affirming the conviction, purported to follow Brandenburg but interpreted it as requiring only that the defendant's speech have had a "tendency to lead to violence." 42 The

39414 U.S. 105 (1973).

19 Hess v. State, 260 Ind. 427, 435, 297 N.E.2d 413, 418 (1973).

" 414 U.S. at 107.

12 Hess v. State, 260 Ind. 427, 429, 297 N.E.2d 413, 415 (1973), quoting Whited v. State, 256 Ind. 386, 391, 269 N.E.2d 149, 152 (1971). See also 260 Ind. at 431, 297 N.E.2d at 416. In Whited the court, per Judge Hunter, had upheld a conviction under the same disorderly conduct statute as in Hess for shouting loud obscenities at police officers, finding that

due to First Amendment freedoms a statute such as the one here in question must be read to require that any prohibited speech related activity must be proscribed because it has a tendency to lead to violence.

256 Ind. at 391, 269 N.E.2d at 152 (emphasis in original). The Whited court concluded that defendant's speech had such a tendency. Whited did not cite Brandenburg and was decided 
majority said that since Hess's statement surpassed theoretical advocacy of violence,

[t]he trial court was justified in finding that the statement was intended to incite further lawless action on the part of the crowd in the vicinity of appellant and was likely to produce such action. ${ }^{43}$

Judge Hunter dissented on the ground that the majority erred in interpreting Brandenburg. He claimed that neither of the two Brandenburg requirements had been met, that Hess neither intended to incite imminent lawless action nor were his words likely to incite imminent lawless action. Judge Hunter contended that:

The evidence shows that appellant was not exhorting the crowd. . . . Even if it were held that appellant intended to incite the crowd, there is still no evidence that lawless action would occur immediately, as the people in the crowd did not consider it an exhortation. ${ }^{44}$

Thus, he concluded, Hess could not, under the circumstances, be punished for his speech.

The United States Supreme Court, accepting the invitation to clarify Brandenburg, rose to the occasion by rediscovering the word "imminent" and, like Judge Hunter, underlined it for emphasis. In a per curiam opinion expressing the views of six members of the Court, it held that Hess's statement was, under the circumstances, constitutionally protected. The Court stated that Hess's statement, even taken at its worst, could not be punished because it amounted to nothing more than advocacy of illegal action at some future time. After quoting the Brandenburg formula, the Court directly disapproved the reasoning of the Indiana Supreme Court:

prior to Gooding v. Wilson, 405 U.S. 518 (1972), which required a threat of immediate violence before words such as those of the defendant in Whited became unprotected "fighting words." See note 47 infra and text and note at note 44 infra.

43 260 Ind. at 430,297 N.E.2d at 415.

"Id. at 436-37, 297 N.E.2d at 418-19 (Hunter, J., dissenting) (emphasis in original). Judge Hunter also thought that defendant's words did not qualify as "fighting words" under Gooding v. Wilson, 405 U.S. 518 (1972), because they did not create a threat of immediate violence. Reading Brandenburg in light of Gooding, see note 47 infra, the judge essentially repudiated his opinion in Whited, see note 42 supra:

The majority . . . holds that the test established in Whited (with pure speech there must be a "tendency to lead to violence") is the same test as Brandenburg. This is simply not the case. Brandenburg would require that the speech be likely to lead to imminent or immediate violence. Requiring only a tendency and not requiring some immediate threat fails to meet the constitutional standards established in Gooding $v$. Wilson . . . . Id. at $435-36,297$ N.E.2d at 418. 
Since the uncontroverted evidence showed that Hess's statement was not directed to any person or group of persons, it cannot be said that he was advocating, in the normal sense, any action. And since there was no evidence, or rational inference from the import of the language, that his words were intended to produce, and likely to produce, imminent disorder, those words could not be punished by the State on the ground that they had "a "tendency to lead to violence." "45

Thus the Court agreed with Judge Hunter's dissent that the record did not show that Hess had advocated action, as required by Dennis and Yates, as well as by Brandenburg; or that Hess had either intended to produce imminent disorder or had spoken in a way likely to produce imminent disorder. ${ }^{46}$ In other words, the Court affirmed that Brandenburg embodies both the "incitement" and the "imminence" tests. ${ }^{47}$

${ }^{45} 414$ U.S. at 108-09. The Court also thought defendant's words were not "fighting words." Id. at 107-08. Chief Justice Burger and Justices Blackmun and Rehnquist dissented.

1s The structure of the Supreme Court opinion in Hess follows that of Judge Hunter's dissent in the Indiana Supreme Court, which in turn adopted the argument of Professor Thomas Schornhorst's brief for Hess. The brief insisted that the State had the burden of showing that Hess's words "constituted a 'clear and present danger' within the meaning of the Brandenburg standard," Brief for Appellant at 17, 260 Ind. 427, 297 N.E.2d 413 (1973), and further defined that standard to require the State to show "(1) that appellant advocated use of force or law violation; and (2) that such advocacy was directed to inciting or producing imminent lawless action; and (3) that such advocacy was likely to produce such action under the circumstances." Id. at 19 (emphasis in original).

${ }^{47}$ The outcome in Hess may have been foreshadowed a year earlier in Gooding v. Wilson, 405 U.S. 518 (1972). In Gooding, John Wilson, a black field secretary for the Student Nonviolent Coordinating Committee (SNCC), was charged with using opprobrious and abusive language while picketing an induction center in opposition to the Vietnam War. When inductees arrived, the picketers sought to block the doors so that the inductees could not enter. Police officers attempted to remove the demonstrators. There was a scuffle, and Wilson said: "White son of a bitch, I'll kill you," "You son of a bitch, I'll choke you to death," and "You son of a bitch, if you ever put your hands on me again, I'll cut you all to pieces." Wilson v. State, 223 Ga. 531, 534, 156 S.E.2d 446, 449 (1967).

The trial court found Wilson guilty under the Georgia disorderly conduct statute and the Georgia Supreme Court affirmed. Wilson sought a writ of habeas corpus which was granted by the federal district court, relying on the just-decided Brandenburg case. 303 F. Supp. 952 (N.D. Ga. 1969). The circuit court of appeals affirmed, 431 F.2d 855 (5th Cir. 1970), as did the United States Supreme Court.

The Supreme Court did not hold that Wilson's language was protected by the first amendment, but held 5-2 that the disorderly conduct statute under which Wilson was convicted was unconstitutionally overbroad and burdensome to other, protected speech. While the Court analyzed the case in terms of "fighting words," see Chaplinsky v. New Hampshire, 315 U.S. 568 (1942), and unlike the district court did not cite Brandenburg, the common ground with Brandenburg is suggested by the Court's statement that the Georgia statute could have been found constitutional had the state courts construed it to apply only when there was a "likelihood that the person addressed would make an immediate violent response." See note 44 supra. 
In general, the lower courts have interpreted Brandenburg consistently with the Supreme Court's decision in Hess. Although there have been some spectacular exceptions, ${ }^{48}$ on the whole the lower courts have protected speech unless it advocated present, or imminent, or immediate lawless action. ${ }^{48}$ Leary $v$. United States ${ }^{50}$ is an excellent example of a lower court reading Brandenburg properly. Dr. Timothy Leary, convicted for smuggling marijuana, challenged a district court's denial of bail pending appeal. The district court denied bail because "he [Leary] has openly advocated a violation of these laws" and therefore "would pose a danger to the community if released." Citing Brandenburg, the Fifth Circuit remanded to allow the district judge to specify whether he had in mind something more than "advocacy falling short of actual incitement to imminent unlawful conduct." If not, bail would be proper unless the appeal was frivolous or the trial judge feared that the appellant would flee if freed.

th See, e.g., Pickens v. State, 466 S.W.2d 563 (Tex. Crim. App. 1971), denial of writ of habeas corpus aff'd, 497 F.2d 981 (5th Cir.), cert. denied, 419 U.S. 880 (1974). Pickens, a black man on probation pursuant to a ten-year suspended sentence, was upset by the shooting of a friend in a street in Amarillo, Texas. An ambulance was slow in arriving. At the hospital, Pickens, still agitated, was alleged to have stated outside the emergency room "that if we all rushed them, we can get in; they can't stop us." Nobody did rush in, there were no arrests, and Pickens denied making the statement. His probation was nonetheless revoked, over a dissent in the Texas court which relied on Schenck, 466 S.W.2d at 566-67 (Morrison, J., dissenting) and one in the circuit court which relied on Brandenburg and Hess, 497 F.2d at 988-89 (Rives, J., dissenting). See also Acanfora v. Board of Education, 359 F. Supp. 843 (D. Md. 1973), aff'd on other grounds, 491 F.2d 498 (4th Cir. 1974) (transfer of school teacher because of homosexuality upheld because teacher's media appearances to present his case to the public were "unnecessary"); Commonwealth v. Belgrave, $217 \mathrm{~Pa}$. Super. 297, 269 A.2d 317 (1970), rev'd on other grounds, $445 \mathrm{~Pa}$. 311, 285 A.2d 448 (1971) (conviction for inciting to riot upheld where appellants-students failed to stand during singing of national anthem before football game urging others to do the same and disturbances broke out during halftime and after the game).

" Thus the published statement of a union dissident that "[i]t is comforting to have wildcats in our arsenal of weapons, just in case," even if made in a mistaken belief that workers have a constitutional right to engage in wildcat strikes, still "falls far short of being 'incitement to imminent lawless action.' Brandenburg v. Ohio." Holodnak v. Avco Corp., 381 F. Supp. 191, 195, 203 (D. Conn. 1974), aff'd except for the award of punitive damages, 514 F.2d 285 (2d Cir. 1975). For recognition by other lower courts of the Brandenburg holding that speech is protected unless it advocates imminent lawless action, see, e.g., Holiday Magic, Inc. v. Warren, 357 F. Supp. 20, 24 (E.D. Wis. 1973), vacated and remanded for convening of three-judge court, 497 F.2d 687 (7th Cir. 1974); Fuller v. Scott, 328 F. Supp. 842, 850 (M.D. N.C. 1971) (dismissed on other grounds); Jackson v. Ellington, 316 F. Supp. 1071, 1075 (W.D. Tenn. 1970), appeal dismissed, 404 U.S. 811 (1971); State v. Tages, 10 Ariz. App. 127, 130, 457 P.2d 289, 292 (1969); State v. Jahr, 114 N.J. Super. 181, 275 A.2d 461 (1971); State v. Cappon, 118 N.J. Super. 9, 19, 21, 285 A.2d 287, 293, 294 (1971).

so 431 F.2d 85, 89 (5th Cir. 1970).

s1 Id. at 85. 
In sum, then, determining the meaning of the Brandenburg test is no longer of great difficulty. Speech is unprotected under Brandenburg only when it (a) advocates imminent lawless action, and (b) is likely to produce imminent lawless action. The problem is not the content of the test. The problem is whether Congress can live with it, ${ }^{52}$ and whether the Supreme Court will apply it.

52 If Congress passed a law abridging speech protected by the first amendment, the Supreme Court would have the duty of voiding the law. Still, one must recognize that the Court might relax its principles under intense Congressional pressure, such as that being generated by the successive versions of an omnibus bill to reform the Federal Criminal Code introduced in the 93rd and 94th Congresses redefining and expanding the crime of seditious advocacy.

Two drafts were introduced in 1973: S. 1, 93rd Cong., 1st Sess. § 2-5B3 (1973); S. 1400, 93rd Cong., 1st Sess. § 1103 (1973).

S. 1400 was reintroduced in 1975 , with only minor changes in the pertinent section as $S$. 1, 94th Cong., 1st Sess. (1975). Section 1103 of the 1975 bill read as follows at the time it was introduced:

\$ 1103. Instigating Overthrow OR Destruction of the Government

(a) OFFENSE.-A person is guilty of an offense if, with intent to bring about the forcible overthrow or destruction of the government of the United States or of any state as speedily as circumstances permit, he:

(1) incites other persons to engage in conduct that then or at some future time would facilitate the forcible overthrow or destruction of such government; or

(2) organizes, leads, recruits members for, or participates as an active member in, an organization or group that has as a purpose the incitement described in paragraph (1).

(b) Grading.-An offense described in this section is a Class $\mathrm{C}$ felony.

Section 2301 of the bill punishes the felony described in Section 1103 by up to 15 years' imprisonment.

Little commentary is needed to underline the ways in which the 1975 bill in its original form departed from the Brandenburg test. The requirement of present, or imminent, or immediate lawless action, both as a goal of advocacy and as objective likelihood, was abandoned. Instead S. 1 in its original form required (a) intent to overthrow the government "as speedily as circumstances permit," and (b) incitement of conduct that "then or at some future time" would "facilitate" the overthrow of the government. As one analyst observed, "the most theoretical proposals in the most unlikely circumstances carry penalties up to 15 years. . . " Schwartz, The Proposed Federal Criminal Code. The Administration's Bill S. 1400, 13 CRIM. L. REP. 3265, 3273 (1973).

Section 1103 was amended in committee, however, so as to conform superficially to the Brandenburg test. The revised section reads as follows:

$\S$ 1103. Instigating Overthrow or Destruction of the Government

(a) OFFENSE.-A person is guilty of an offense if, with intent to bring about the forcible overthrow or destruction of the government of the United States or of any state, he:

(1) incites other persons to engage in imminent lawless conduct that would facilitate the forcible overthrow or destruction of such government; or

(2) organizes, leads, or recruits members for a group that has as a purpose the incitement described in paragraph (1); or

(3) Participate [sic] as an active member in a group that he knows has as a purpose the incitement described in paragraph (1). . . . (emphasis added).

S. 1 as amended nevertheless still changes the Brandenburg test significantly. By excising the phrases "as speedily as circumstances permit" and "then or at some future time" the 


\section{Coverage of the Brandenburg Test}

Although Hess eliminated the uncertainty regarding the content of the Brandenburg test, the Supreme Court has not clarified the scope of the test's coverage. Brandenburg clearly applies when the state seeks to impose criminal sanctions for the advocate's speech, ${ }^{53}$ but the Court has divided over whether Brandenburg should control when noncriminal sanctions are imposed or when it is argued that the special needs of a government institution require diluting or abandoning the stringent Brandenburg standards. As will be seen, the Justices have not often clearly separated these issues, perhaps because they usually appear together: the institutions with noncriminal sanctions at their disposal tend also to be those which, because of their special societal roles, are argued to require exemption from Brandenburg..$^{54}$

Making sense out of the Court's uncertain treatment of Brandenburg's coverage is complicated by the fact that prior to

amended section may appear to restore the Brandenburg requirement of imminent lawless action, the more so as the words "imminent lawless" are in fact inserted. The word "facilitate" is retained, however, and it can only mean that if $A$, an imminent, lawless, but relatively innocuous act, can be held to facilitate $B$, the violent overthrow of the government at some future time, then the advocate of $A$ is punished as if he or she had advocated $B$. Cf. note 134 infra. Furthermore, neither the original language of Section 1103 nor the language as amended contains the last clause of the Brandenburg test, requiring that speech not only advocate imminent lawless action, but be "likely to incite or produce such action," before losing constitutional protection.

Even as amended, S. 1 would largely eliminate the emphasis placed by the Brandenburg test on a close temporal nexus between speech and its consequences. See Hearings on S. 1400 and S. 1 Before the Subcomm. on Criminal Laws \& Procedures of the Senate Judiciary Comm., 94th Cong., 1st Sess., pt. 11, at 7952-53 (1974), reprinted at 120 Conc. REc. 20, 50405 (daily ed. Dec. 4, 1974).

ss Brandenburg and Hess were both criminal prosecutions. It also appears that if a defendant was prosecuted for advocacy under the Smith Act, the Brandenburg test would now apply. See text and notes at notes 18-38 supra. But cf. Parker v. Levy, 417 U.S. 733 (1974), discussed in text and notes at notes 109-27 infra. Brandenburg would, it appears, also apply in an injunctive proceeding. Eight months before Brandenburg the Court considered the injunction of speech activity in Carroll v. Commissioners of Princess Anne, 393 U.S. 175 (1968). Although the case was decided on procedural grounds without reaching the issue whether the alleged danger justified prior restraint of speech, the Court indicated that prior restraint of speech is presumptively invalid but might be appropriate in "special limited circumstances in which speech is so interlaced with burgeoning violence that it is not protected by the broad guarantee of the First Amendment." Id. at 180; see National Socialist White People's Party v. Ringers, 473 F.2d 1010 (4th Cir. 1973), note 100 infra; cf. text and notes at notes 91-100 infra.

st Actually, virtually all institutions can employ noncriminal sanctions; the institutional authorities can fire or demote the employees. Certain institutions, however, have noncriminal sanctions at their disposal in addition to such employment-related sanctions. A college, for example, can suspend a student from class or withhold a diploma. It is to institutions with these somewhat unique types of noncriminal sanctions that this comment refers. 
Brandenburg it had consistently held that the level of speech protection is not dependent on the character of the sanction imposed-that is, whether it is civil or criminal..$^{55}$ The rationale for this doctrine, that civil disabilities chill speech as effectively as criminal punishment, ${ }^{56}$ continues unimpaired by logic or holding, and a majority of the Court continues to honor it at least in the breach. ${ }^{57}$ The Court's performance is further complicated because it has been less than lucid in identifying which institutional needs it believes would be impaired by applying Brandenburg and, more importantly, in explaining why.

This section closely and critically examines the Supreme Court cases since Brandenburg where these issues have played a pivotal role. A framework is then suggested within which the Court could protect important institutional needs without abandoning either Brandenburg or the doctrine that the same speech test applies whether criminal or civil sanctions are at stake.

\section{A. The Debate Within the Court over Coverage of the Brandenburg Test}

1. The Bar Admission Cases. A relaxation of Brandenburg first became apparent in the 1971 trilogy of bar admission cases, Baird v. State Bar of Arizona, ${ }^{58}$ In re Stolar, ${ }^{59}$ and Law Students Civil Rights Research Council, Inc. v. Wadmond.$^{60}$ In Baird appellant refused to answer a bar application question which asked whether she was or had "ever been a member of the Communist Party or any organization that advocates overthrow of the United States Government by force or violence." ${ }^{61}$ In Stolar appellant re-

${ }^{35}$ See, e.g., United States v. Robel, 389 U.S. 258 (1967) (public employment); Keyishian v. Board of Regents, 385 U.S. 589 (1967) (public employment); Bond v. Floyd, 385 U.S. 116 (1966) (public office); Elfbrandt v. Russell, 384 U.S. 11 (1966) (public employment). See generally Note, Civil Disabilities and the First Amendment, 78 YALE L.J. 842 (1969).

The issue of the first amendment's protection against noncriminal or, as he termed them, partial sanctions, was of particular concern to Professor Kalven. At his death Professor Kalven left an unfinished manuscript on the first amendment about 1,000 pages in length, which the family kindly permitted me to read. More than a third of the manuscript deals with noncriminal sanctions.

ss "Whether or not loss of public employment constitutes 'punishment,' . . . there can be no doubt that the repressive impact of the threat of discharge will be no less direct or substantial." Keyishian v. Board of Regents, 385 U.S. 589, 607 n.11 (1967).

${ }^{37}$ See, e.g., Communist Party of Indiana v. Whitcomb, 414 U.S. 441, 448-50 (1973); Perry v. Sindermann, 408 U.S. 593, 597 (1972).

58 401 U.S. 1 (1971).

39 401 U.S. 23 (1971).

so 401 U.S. 154 (1971).

B1 401 U.S. at 14. 
fused to answer a bar application question that asked whether he was or had been "a member of any organization which advocates the overthrow of the government of the United States by force." 62 In each case appellant was denied admission to the bar for refusal to answer, and in each the Supreme Court held the denial unconstitutional. Justice Black, writing for himself and Justices Douglas, Brennan and Marshall in Baird and Stolar, found "no legitimate state interest which is served by a question which sweeps so broadly into areas of belief and association protected against government intrusion," ${ }^{63}$ and he concluded that the applicants' "views and beliefs are immune from bar association inquisitions designed to lay a foundation for barring an applicant from the practice of law."64

Justice Stewart, whose vote was necessary to make up the majority in Baird and Stolar, did not concur with the reasoning of the plurality opinions. He filed brief concurrences in both cases that are interesting when compared to his extended and seemingly inconsistent majority opinion in Wadmond. Without specifying the state interests that would justify the asking of a properly limited membership question in a bar application, he found the questions asked in Baird and Stolar to be overbroad under Scales v. United States ${ }^{65}$ because they were not limited to "knowing membership in an organization advocating the overthrow of the Government by force or violence, on the part of one sharing the specific intent to further the organization's illegal goals." ${ }^{\text {"B }}$ Chief Justice Burger and Justices White, Blackmun and Harlan dissented in both cases. ${ }^{67}$

2401 U.S. at 27.

on re Stolar, 401 U.S. 23, 30 (1971) (Black, J.).

" Baird v. State Bar of Arizona, 401 U.S. 1, 8 (1971) (Black, J.). See also In re Stolar, 401 U.S. 23, 30 (1971) (Black, J.). Justice Black rejected the argument that the question was permissible because an affirmative answer would not compel exclusion, but would only trigger investigation into whether the applicant's membership had been knowing and with specific intent. See In re Stolar, 401 U.S. 23, 29-30 (1971); Brief for Respondent at 6, In re Stolar, 401 U.S. 23 (1971); Brief for Respondent in Opposition of Certiorari at 12-13, In re Stolar, 401 U.S. 23 (1971); Law Students Civil Rights Research Council, Inc. v. Wadmond, 401 U.S. 154, 182 (1971) (Black, J., dissenting).

"s 367 U.S. 203 (1961). Scales upheld the membership clause of the Smith Act. The Court's finding that the Act contemplated punishing only knowing and active membership in a group that advocated violent overthrow of the government was central to its conclusion. See text and note at note 78 infra.

" Baird v. State Bar of Arizona, 401 U.S. 1, 9 (1971) (Stewart, J., concurring). The plurality agreed with Justice Stewart that it would be impermissible under Shelton v. Tucker, 364 U.S. 479 (1960), for the bar examiners to ask an applicant to list all organizations of which he was or ever had been a member or all organizations of which he had become a member since registering as a law student. In re Stolar, 401 U.S. 23, 28-29 (1971) (Black, J.); id. at 31 (Stewart, J.).

"Justice Harlan joined Justice Blackmun's dissents in Baird and Stolar and Justice 
In Wadmond, the only case of the three to produce an "Opinion of the Court," Justice Stewart joined with the four dissenters from Baird and Stolar to form a new majority. This time writing for the majority, Justice Stewart held that New York could constitutionally require its applicants to the bar to answer the following questions:

26. (a) Have you ever organized or helped to organize or become a member of any organization or group of persons which, during the period of your membership or association, you knew was advocating or teaching that the government of the United States or any state or political subdivision thereof should be overthrown or overturned by force, violence or any unlawful means? _ If your answer is in the affirmative, state the facts below.

(b) If your answer to (a) is in the affirmative, did you, during the period of such membership or association, have the specific intent to further the aims of such organization or group, . . .88

Justice Stewart, again relying on Scales, ${ }^{69}$ found that Question 26, when taken as a whole, was "precisely tailored to conform to the relevant decisions of this Court." could divide the question into two parts and ask the bar applicant first about mere membership and then about intention to further the group's goals. This could be done even though the first question standing alone would not meet the Scales test. Justice Stewart said the division was permissible under Konigsberg $v$. State Bar, ${ }^{71}$ which had held "that Bar examiners may ask about Communist affiliations as a preliminary to further inquiry into the nature of the association and may exclude an applicant for refusal to answer."72 Perhaps uncomfortable with the apparent contradiction between this reasoning and his conclusion in Stolar, where appellee had also

Stewart's opinion in Wadmond, adding a brief opinion in which he stated:

I do not dispute that the First Amendment . . . prevents states from denying admission to candidates merely because of theoretical beliefs in the "right" of revolution, but I do maintain that there is no constitutional barrier to denying admission to those who seek entry to the profession for the very purpose of doing away with the orderly processes of law ....

In re Stolar, 401 U.S. 23, 35-36 (1971) (Harlan, J., concurring). (1971).

${ }^{8 s}$ Law Students Civil Rights Research Council, Inc. v. Wadmond, 401 U.S. 154, 164-65

69 Id. at 165 .

70 Id.

7366 U.S. 36 (1961). See also In re Anastaplo, 366 U.S. 82 (1961).

72401 U.S. at 165-66 \& n.19. 
urged that an answer of "yes" would lead not to automatic rejection but to further investigation of the applicant's associations, ${ }^{73}$ Justice Stewart concluded:

Surely a State is constitutionally entitled to make such an inquiry of an applicant for admission to a profession dedicated to the peaceful and reasoned settlement of disputes between men, and between a man and his government. ${ }^{74}$

Justice Stewart did not, however, attempt further to reconcile his Wadmond position with his seemingly contradictory votes in Baird and Stolar ${ }^{75}$ or explain why Brandenburg did not compel the opposite result in Wadmond.

Justice Black joined by Justice Douglas, and Justice Marshall joined by Justice Brennan, attacked Justice Stewart's position in separate dissents on the same two basic grounds. They denied that part (a) of the question could be saved by part (b), pointing out the inconsistency between Justice Stewart's positions in Baird and Stolar and in Wadmond..$^{78}$ More importantly, they denied that the Scales test of advocacy relied on by the majority survived Brandenburg:

[In Brandenburg] the Court held that advocacy of violence or the joining with others to do so could not be proscribed "except where such advocacy is directed to inciting or producing imminent lawless action and is likely to incite or produce such action."

"See note 64 supra.

3401 U.S. at 166.

is Justice Stewart may have assumed that the "intent" aspect of the Wadmond question distinguished that case from Baird and Stolar. If so, Justice Stewart should have explained why, in light of Brandenburg, that distinction was controlling. See text and note at note 78 infra. Brandenburg would seem to permit inquiry into membership only of groups that advocate imminent lawless action. Since membership in other organizations that advocate nonimminent overthrow-be it with specific intent to further their aims or not-is legal, the state should have no interest in inquiring about such ties.

7 Id. at 182-83 (Black, J., dissenting); id. at 197 n.10 (Marshall, J., dissenting); see text and notes at notes $64 \& 73$ supra. If Baird and Stolar are read as holding that the bare membership-in-a-group-that-advocates question cannot be asked even for the limited purpose of further inquiry, then Justice Blackmun seems correct that those cases in effect overrule Konigsberg and Anastaplo, despite what he called Justice Stewart's "definite bow in their direction" in Baird. Baird v. State Bar of Arizona, 401 U.S. 1, 13 (1971) (Blackmun, J., dissenting). Justice Stewart's "bow" consisted of asserting that those cases still permit "simple" inquiry into party membership. Id. at 9. But Konigsberg and Anastaplo can be reconciled with Baird and Stolar only if the former cases now form a special rule for inquiring into membership in the Communist Party, hardly a principled result. Further, the Wadmond majority, by relying on Konigsberg to justify Question 26(a) because it led to the further inquiry in 26 (b), destroyed even this hope of reconciliation. 
... However, [Question 26] does not specify that the organization's advocacy must have been "directed to inciting or producing imminent lawless action" and "likely to produce such action." Thus, for their failure to meet the Brandenburg requirements, the New York questions are overbroad. ${ }^{77}$

This point is well taken. As Justice Stewart noted in his opinions in both Baird and Wadmond, one could be punished under Scales for knowing membership in an organization advocating overthrow of the Government by force or violence, on the part of one sharing the specific intent to further the organization's illegal goals. However, Justice Stewart failed either to realize or to acknowledge that Scales had implicitly incorporated the Dennis-Yates rule that speech advocating even non-imminent danger could be proscribed or punished..$^{78}$ But under Brandenburg, only advocacy of imminent unlawful action can be punished; advocacy of action at some uncertain time in the future is constitutionally protected. To this extent Brandenburg impaired the authority of Dennis and Yates and, through them, Scales.

It is disturbing that Justice Stewart, speaking for the Wadmond majority, did not even cite Brandenburg, let alone respond to this argument. Although all nine of the justices recognized the state's interest in restricting bar admission to persons of "character and fitness," Justice Stewart did not discuss why it was necessary to, in effect, relax Brandenburg's imminence requirement in order to protect this interest; that is, he did not explain why the bar would be more vulnerable to persons belonging to an organization that advocated overthrow of the government as an abstract doctrine

701 U.S. at 183-84 (Black, J., dissenting); accord, id. at 197 (Marshall, J., dissenting).

${ }^{78}$ In Scales v. United States, 367 U.S. 203 (1961), the Court approved an instruction to the jury that, in order to convict for Communist Party membership under the Smith Act, it must find:

(1) the Communist Party advocated the violent overthrow of the Government, in the sense of present "advocacy of action" to accomplish that end as soon as circumstances were propitious; and (2) [defendant] was an "active" member of the Party . . . with knowledge of the Party's illegal advocacy and a specific intent to bring about violent overthrow "as speedily as circumstances would permit."

Id. at 220. The Scales Court noted that:

As both sides appear to agree that the 'clear and present danger' doctrine, as viewed and applied in Dennis . . . also reaches the membership clause of the Smith Act, and since the petitioner for certiorari tenders no issue as to the method of applying it here, we do not consider either question.

Id. at 230 n.21. The Court nonetheless took pains to emphasize that "Dennis and Yates have definitely laid at rest any doubt that present advocacy of future action for violent overthrow satisfies statutory and constitutional requirements equally with advocacy of immediate action to that end." Id. at 251 (emphasis in original). 
than would society at large.

Other members of the Wadmond majority have, however, offered clues that might explain the rationale of the Wadmond holding. Justice White, dissenting in Baird and Stolar, expressed the view that the state could exclude an applicant if "the applicant will . . . advise lawless conduct as a practicing lawyer" or if it appeared that he was "without comprehension that advising lawless conduct is incompatible with professional standards."79 Granting that an attorney may justifiably be punished for advising a client to pursue an unlawful course of action, however, it does not logically follow that an attorney's speech outside or prior to his undertaking of a professional role should be subject to a test more lax than Brandenburg, nor is there any basis in prior decisions for such a position. Nor can exclusion from the bar be predicated on the assumption that a person who has engaged in advocacy protected by Brandenburg that would have been unprotected under DennisYates or has belonged to a group that engaged in such advocacy will, as an attorney, advise clients to act lawlessly..$^{80}$ There is no warrant for assuming that those who believe in certain abstract radical doctrines will be less capable of representing their clients' best interests than, say, a states rights conservative who believes that federal regulation is fundamentally immoral.

Justice Blackmun offered another argument for the Wadmond majority position in his Baird dissent. He asserted "the State has a measure of a right to protect itself. Its area of vulnerability is nowhere greater than in its courts and its judicial process. . . . See Illinois v. Allen, 397 U.S. 337 (1970); Mayberry v. Pennsylvania, 400 U.S. 455 (1971)." 81 The two cases cited, though, dealt with courtroom misconduct by defendants, not attorneys, and thus are not persuasive authorities. Again, moreover, Justice Blackmun did not offer a reasoned justification for concluding that persons who engage in strong but legal speech outside the courtroom or who belong to a group that engages in such speech should be presumed incapable of conforming their conduct to judicial standards inside the courtroom.

The views of Justices White and Blackmun were those of the dissenters in Baird and Stolar; they conceded that their basic views differed from those of the majority in those cases. ${ }^{82}$ The real puzzle

7" Baird v. State Bar of Arizona, 401 U.S. 1, 10, 11 (1971) (White, J., dissenting).

so See also note 84 infra.

1 401 U.S. at 22 (Blackmun, J., dissenting).

s2 See also Justice Harlan's view, quoted at note 67 supra. 
is Justice Stewart's change in position from Baird and Stolar to Wadmond, a puzzle he never attempted to explain. The fact that denial of admission to the bar, rather than criminal punishment, could result from the applicants' prior activities in Wadmond cannot account for Justice Stewart's inconsistency; all three cases involved exclusion. Moreover, he seemed to agree with Justice Black's statement that "it should make no difference that New York threatens to exclude people from their chosen livelihood rather than to put them in jail."83 Nor can his different opinions be reconciled by look-

${ }^{83}$ Law Students Civil Rights Research Council, Inc. v. Wadmond, 401 U.S. 154, 184 (Black, J., dissenting); see Baird v. State Bar of Arizona, 401 U.S. 1, 9 (Stewart, J., concurring). But see Cole v. Richardson, 405 U.S. 676 (1972), where the distinction between civil and criminal sanctions may have been decisive. The Court there upheld, $4-3$, the dismissal of a sociologist from state employment for refusing to take the following oath:

I do solemnly swear (or affirm) that I will uphold and defend the Constitution of the

United States of America and the Constitution of the Commonwealth of Massachusetts and that I will oppose the overthrow of the government of the United States of America or of this Commonwealth by force, violence or by any illegal or unconstitutional method. Id. at 677-78 (emphasis added). All members of the Court agreed that the first clause of the oath was permissible under past decisions, which had interpreted "support and uphold" oaths as "calling simply for an acknowledgement of a willingness to abide by "constitutional processes of government," " $i d$. at 682, quoting Bond v. Floyd, 385 U.S. 116, 135 (1966), rather than exacting a promise to refrain from constitutionally protected advocacy. The Court disagreed, however, over the second half of the oath. Chief Justice Burger, writing for himself and Justices Stewart, White and Blackmun (Justices Stewart and White filed a brief concurrence, id. at 687), reaffirmed decisions holding that "employment [may not] be conditioned on an oath that one has not engaged, or will not engage, in protected speech activities," $i d$. at 680 , or on an oath "denying past, or abjuring future, associational activities within constitutional protection," id. Denying Justice Douglas's argument in dissent that " $[t]$ his oath ... requires that appellee "oppose' that which she has an indisputable right to advocate," $i d$. at 689 (footnote omitted), the Chief Justice interpreted the second clause as imposing no obligation in addition to that of the first, id. at 683-85, concluding: "That the second clause may be redundant is no ground to strike it down; we are not charged with correcting grammar but with enforcing a constitution." Id. at 684 . Relying on this interpretation, which was vigorously disputed by the dissenters, see $i d$. at $689 \&$ n.3 (Douglas, J., dissenting) and $i d$. at 692-97 (Marshall, J., dissenting), the Chief Justice also found that the oath was not unconstitutionally vague. Asserting that violation of the oath "is punishable only by a prosecution for perjury," $i d$. at 685 (footnote omitted), he noted that there had been no such prosecution since 1948 and concluded:

Were we confronted with a record of actual prosecutions or harassment through threatened prosecutions, we might be faced with a different question.

Id. at 685 . The difficulty with this reasoning is that the speech and associations of one who refuses to take the oath because of uncertainty of its coverage and unwillingness to commit perjury, and who is denied employment for that reason, are penalized just as surely as if she had taken the oath and been prosecuted. In terms of the Court's previous unwillingness to distinguish between civil and criminal sanctions, see text and notes at notes 55-57 supra, Justice Douglas scored a point with his rejoinder:

Here, appellee has been discharged from employment and denied her source of livelihood because of her refusal to take an unconstitutional oath. If the oath suffers from constitutional infirmities, then it matters not whether the penalties imposed for refusing to subscribe to it were criminal or the denial of employment. 
ing at the content of the questions at issue-whether the questions concerned membership with intent rather than mere membership. Although Wadmond can be logically distinguished from Baird and Stolar on this ground, this distinction would seem to be insubstantial after Brandenburg-under which even intentional advocacy of violent overthrow is protected unless it is advocacy of imminent overthrow. Justice Stewart's opinions in the bar admission cases thus represent an unsolved puzzle. Even though one can conclude that some unarticulated conception of compelling institutional needs enabled Justice Stewart to justify allowing bar examiners to question applicants about certain types of membership, one is at a loss to understand why Justice Stewart failed to heed the appeals of the Wadmond dissenters to consider Brandenburg and explain his split votes. ${ }^{84}$

2. Healy v. James. The issues which seem to underlie the bar admission cases-the identification and protection of institutional needs and the distinction between civil and criminal sanctions in advocacy cases-were treated somewhat more explicitly in Healy $v$. James ${ }^{85}$ The Court there considered a challenge to the refusal of the president of a state-supported college to accord campus recognition and privileges to a local chapter of Students for a Democratic Society (SDS). Reviewing the record from two campus hearings which formed the basis of the president's decision, Justice Powell, writing

Id. at 689 n.1 (Douglas, J., dissenting). With Richardson, compare Communist Party of Indiana v. Whitcomb, 414 U.S. 441 (1973), discussed in text and notes at notes 128-33 infra, where the Court refused to distinguish between civil and criminal penaities and applied the Brandenburg test to a loyalty oath.

st With Wadmond, compare Siegel v. Committee of Bar Examiners, 10 Cal. 3d 156, 514 P.2d 967, 110 Cal. Rptr. 15 (1973), where the Supreme Court of California held that the bar examiners had erred in excluding an applicant for allegedly falsely stating that he had never advocated violence in his speeches. The court held that the evidence did not support a finding that the applicant knew the statements were untrue and had an intent to deceive. The court carefully reviewed the content of the speeches and the circumstances in which they were made and considered whether the applicant could have been excluded for the underlying speeches rather than for his alleged deceit. Unlike the Wadmond majority, the court applied Brandenburg full-force:

[I]t seems apparent that the [bar examiners'] determination to rest the denial of certification on petitioner's alleged lies rather than directly on the content of the speeches made by him was based upon the conclusion that those speeches lay within the ambit of constitutional protection and would not support a finding of bad moral character. The Committee's finding that the speeches advocated violence would not have been enough in and of itself to withdraw constitutional protection in the absence of an additional finding that "such advocacy [was] directed to inciting or producing imminent lawless action and [was] likely to incite or produce such action" (citing Brandenburg v. Ohio).

10 Cal. 3 d at 174 n.18, 514 P.2d at 980 n.18, 110 Cal. Rptr. at 28 n.18.

ss 408 U.S. 169 (1972). 
for the Court, concluded that the college and two lower courts had erred in placing the burden of persuasion on SDS, once it had filed an application for recognition in conformity with the college's requirements, to show that its speech-related activities would not be disruptive. ${ }^{86}$ Before reaching this conclusion, the Court also held that withholding official recognition, which meant the chapter could not use campus facilities, was a sufficient impediment to protected activity to permit the first amendment issues to be raised. ${ }^{87}$

Putting aside the misplaced burden of persuasion, Justice Powell went on to review the propriety of four possible bases for the president's decision to withhold recognition and concluded that three were either impermissible under the first amendment or not supported by the evidence, while a fourth required a remand for further evidentiary proceedings. He first said that the local SDS chapter could not be denied recognition because of affiliation with a national organization which "had been associated with disruptive and violent campus activity." Noting that the local chapter had avowed complete independence from the national and had indicated agreement with only some of the national's beliefs, Justice Powell held that the local had been denied its freedom of association because the college had not met its "burden of establishing a knowing affiliation with an organization possessing unlawful aims and goals, and a specific intent to further those illegal aims." 89 Second, he said that the local chapter could not be excluded "for adhering to . . . a philosophy of violence and disruption," because advocacy of even such a philosophy is protected. ${ }^{80}$

Third, Justice Powell observed that the president might have excluded the chapter because of a likelihood that its activities would cause disruption on campus. Here the opinion becomes difficult to follow. After citing Brandenburg as the relevant test for considering the propriety of such a decision, Justice Powell wrote:

${ }^{88}$ Id. at $184-85$, relying on Speiser v. Randall, 357 U.S. 513 (1958).

${ }_{87} 408$ U.S. at 181-84.

ss Id. at 185 .

89. at 185-87. In applying this test of organizational advocacy, the Court cited, inter alia, Scales and Wadmond. See text and notes at notes 77-78 supra. As in his discussion of the third possible reason, Justice Powell's formulation ignored Brandenburg's imminence requirement. Under Scales and Brandenburg, a local affiliate should be denied recognition only if it is knowingly associated with a national organization that advocates imminent lawless action, and is likely to produce such action, and the affiliate specifically intends to further that aim.

so Id. at $187-88$ (footnote omitted). 
In the context of the "special characteristics of the school environment," the power of the government to prohibit "lawless action" is not limited to acts of a criminal nature. Also prohibitable are actions which "materially and substantially disrupt the work and discipline of the school." Tinker v. Des Moines Independent School District, 393 U.S. 503, 513 (1969). Associational activities need not be tolerated where they infringe reasonable campus rules, interrupt classes, or substantially interfere with the opportunity of other students to obtain an education. ${ }^{21}$

Justice Powell then pointed to the college's "Student Bill of Rights" enforce, and concluded that there was no "evidential basis to support the conclusion that [the local chapter] posed a substantial threat of material disruption" in violation of the "Student Bill of Rights"; ${ }^{93}$ hence the president's decision could not be supported on this ground.

This section of the opinion is unaccountably murky. Disregarding the obvious difficulty of determining what noncriminal "materially disruptive" actions are properly considered "lawless action" in the campus context, ${ }^{94}$ the quotation of the Brandenburg test clearly implies that advocacy is protected unless it is "directed to inciting or producing imminent" violation of campus law and is "likely to incite or produce such action." Imminence, it is implied, is required even on campus. Yet the Court was prepared to uphold exclusion of the chapter if it could be shown that it merely "posed a substantial threat of material disruption," or, as the Court said in a footnote, a "likelihood of disruption." is quite unclear; the Court either may have been saying that exclusion can be based on a prediction that the chapter itself will engage in disruptive behavior or it may have been saying that exclusion can

"Id. at 188-89 (footnote omitted).

"Justice Powell said the "Student Bill of Rights":

[P] urports to impose no limitations on the right of college students' organizations "to examine and discuss all questions of interest to them" (emphasis supplied). But it also states that students have no right (1) "to deprive others of the opportunity to speak or be heard," (2) "to invade the privacy of others," (3) "to damage the property of others," (4) "to disrupt the regular and essential operation of the college," or (5) "to interfere with the rights of others." The line between permissible speech and impermissible conduct tracks the constitutional requirement .... .

Id. at 189 (footnote omitted).

is Id.

" Cf. text and note at note 134 infra.

is 408 U.S. at $189-90$ n.20. 
be based on a prediction that the chapter's speech will incite others to engage in disruptive behavior. The way in which this language is read may have important implications for the future vitality of the Brandenburg test.

If, as seems likely in light of the Court's repeated emphasis on the nature of the chapter's behavior and the repeated citation of Brandenburg, Justice Powell was referring only to the chapter's future actions rather than to its speech, then this portion of Healy is unlikely to undermine the vitality of Brandenburg. It then has nothing to do with advocacy. But if, on the other hand, the prediction was about future advocacy, then Healy may signify an unexplained narrowing of Brandenburg's applicability. In order for exclusion to be based on future advocacy, it should be recalled, Brandenburg teaches that the relevant prediction would have to be (1) that future advocacy would be directed to inciting imminent unlawful action, and (2) that it would be likely to produce such action. Yet if Justice Powell's language is read as involving a prediction about future advocacy, permitting exclusion on the basis of a "substantial threat" or a "likelihood" of disruptive advocacy effectively disregards Brandenburg's imminence requirement because the impermissible advocacy is predicted to occur at some uncertain time in the future and, even at that point, seemingly need not be advocacy of imminent lawlessness.

That Healy should be read as involving a prediction about future conduct is suggested by the fact that even before Brandenburg the Court, aware of the danger of permitting penalization of predicted future unlawful advocacy, expressed doubt about the propriety of such punishment. In both Dennis and Yates the defendants had been charged with conspiracy to engage in unlawful advocacy. Chief Justice Vinson's opinion in Dennis seemed to approve punishment of anticipated future unlawful advocacy. The Chief Justice cryptically asserted that his analysis distinguishing "mere" advocacy from advocacy of action "disposes of the contention that a conspiracy to advocate, as distinguished from the advocacy itself, cannot be constitutionally restrained, because it comprises only the preparation. It is the existence of the conspiracy which creates the danger." 96 This statement was severely limited in Yates, however, the Court observing that the Chief Justice's remarks were not necessary to his decision because Dennis involved advocacy which had already taken place, not advocacy still to occur:

${ }^{88} 341$ U.S. at 511. 
The reference of the term "conspiracy," in context, was to an agreement to accomplish overthrow at some future time, . . . rather than to an agreement to speak. . . . It was action, not advocacy, that was to be postponed until "circumstances" would "permit." We intimate no views as to whether a conspiracy to engage in advocacy in the future, where speech would thus be separated from action by one further remove, is punishable under the Smith Act. ${ }^{87}$

If the Yates Court had even the slightest doubts about the propriety of punishing advocacy to take place in the indefinite future, the Healy Court should have had much more substantial doubts about the permissibility of penalizing predicted advocacy; because Brandenburg, decided between Yates and Healy, holds that only advocacy of imminent unlawful action can be punished; it is unlikely that predicted advocacy could meet the imminence requirement. ${ }^{98}$

It would simply not make sense to hold that advocacy cannot be punished except where it constitutes incitement to imminent unlawful action and is likely to produce such action, but also to hold that one may be prevented from speaking altogether because he or she seems likely at some indefinite future time to engage in inciting speech that in turn seems likely to be followed by unlawful action. Exclusion on the basis of predicted future speech and its predicted consequences is unjustifiable if Brandenburg's imminence requirement is to be taken seriously. Thus, of the two ways in which Healy can be read-either Healy held, without explanation, that Brandenburg's imminence requirement is not applicable in judging the propriety of campus advocacy or the Court took a narrower approach and only referred to predictions about future conduct ${ }^{99}$ - the second seems preferable. ${ }^{100}$

17354 U.S. at 323-34 (emphasis in original). S̈ee also Noto v. United States, 367 U.S. $290,298-99$ (1961) (emphasis in original):

[I] $\mathrm{n}$ examining [the] evidence it appears to us that . . . [it] fails to establish that the Communist Party was an organization which presently advocated violent overthrow of the Government now or in the future, for that is what must be proven. . . . [I]t is present advocacy, and not an intent to advocate in the future or a conspiracy to advocate in the future once a groundwork has been laid, which is an element of the crime under the membership clause [of the Smith Act]. infra.

${ }^{28}$ Cf. Kiiskila v. Nichols, 433 F.2d 745 (7th Cir. 1970) (en banc), discussed at note 127

"There is an additional reason for assuming that the discussion in Healy was not directed toward a prediction of the chapter's future speech. Healy involved an attempt by the university to restrict its students. If Healy established the proposition that on-campus student advocacy could be proscribed without meeting Brandenburg's imminence require- 
ment, then the Court would have to decide if this lesser standard of advocacy would also be applicable to professors, guest lecturers or anyone else who happened to be advocating on a college campus. In other words, if Healy is to be read broadly, then the Court would have to explain whether or not a person is stripped of a portion of his first amendment rights merely by stepping on college ground. The fact that the Court did not recognize, let alone discuss, this problem suggests that Healy should not be read in this way.

${ }^{100}$ The fourth possible basis for the president's decision considered in Healy was the possibility that the local chapter had refused to promise to conform its conduct to the "valid" campus rules noted above. Insofar as those rules might cover advocacy, the only promise that could be exacted was that the chapter would refrain from advocacy unprotected under Brandenburg. Cf. Cole v. Richardson, 405 U.S. 676, 680 (1972), quoted at note 83 supra (state cannot exact promise to refrain from constitutionally protected advocacy as condition of public employment). The Court found ambiguities in the evidence regarding whether the chapter had been willing to make such a promise and remanded for further evidentiary proceedings on the point.

See also Tinker v. Des Moines Ind. Community School Dist., 393 U.S. 503 (1969), where the Court held that school administrators had acted improperly by suspending students from classes for wearing black armbands to school to protest the Vietnam War. The Court rejected the administrators' argument that they feared violence would result if the students were allowed to remain in school, stating: "[I]n our system, undifferentiated fear or apprehension of disturbance is not enough to overcome the right to freedom of expression." Id. at 508.

Lower court decisions since Brandenburg dealing with campus disorders fall into three groups. One group, like Healy, involves situations where speech is restricted without any evidentiary showing of danger, imminent or otherwise. In these cases the court can set aside the restriction without reaching the issue of whether the danger is imminent. Thus it was held that one vulgar word in an open letter in the school newspaper constituted neither incitement under Brandenburg nor obscenity under Cohen v. California, 403 U.S. 15 (1971). Thonen v. Jenkins, 491 F.2d 722 (4th Cir. 1973). And it was held that a student newspaper at a black college could not be disciplined for opposing the admission of white students absent a showing of a danger of physical violence or disruption. Joyner v. Whiting, 477 F.2d 456 (4th Cir. 1973). See also Brooks v. Auburn Univ., 412 F.2d 1171, 1173 (5th Cir. 1969).

A more restrictive line of decisions is illustrated by Norton v. Discipline Comm. of $\mathrm{E}$. Tenn. State Univ., 419 F.2d 195 (6th Cir. 1969), cert. denied, 399 U.S. 906 (1970). There students were suspended for distributing leaflets. The leaflets called university administrators "despots," and referred with apparent admiration to students elsewhere who had "seized buildings and raised havoc." Citing Dennis and Schenck, the Sixth Circuit upheld the suspensions. In passing, the majority intimated that the students had "urge[d] a riot," using language condemned by the state and federal anti-riot acts.

Judge Celebrezze dissented, citing both Schenck and Brandenburg. He asserted that Schenck requires an "evidentiary showing of imminent disruption," and that in Brandenburg "the Court held that one could not presume that 'encouragement' of unlawful conduct would reach the stage of incitement." Id. at 208, 211.

Finally, there is a third group of decisions in which courts have applied the full Brandenburg test and disallowed speech restriction because there was no showing of advocacy or danger of imminent disruption. Thus, a California court held that one who distributed leaflets to high school students at most suggesting that "the students come to a meeting and join a group which is organizing a student strike on a date more than three weeks away" was engaged, under Brandenburg, in protected speech. Mandel v. Municipal Court, 276 Cal. App. 2d 649, 673, 81 Cal. Rptr. 173, 188 (1969). See also National Socialist White People's Party v. Ringers, 473 F.2d 1010, 1015 (4th Cir. 1973).

The most dramatic decision in this group of decisions more speech-protective than Healy is In re Brown, 9 Cal. 3d 612, 510 P.2d 1017, 108 Cal. Rptr. 465 (1973). This California Supreme Court decision dealt with an incident in the prolonged upheaval at San Francisco State College. Although "thunderous" chanting and shouting at a midday campus rally led to the dismissal of one class and the disturbance of several others, the court held that the 
Regardless of whether the Healy majority actually relaxed Brandenburg's imminence requirement in its discussion of the third possible basis for the president's decision, ${ }^{101}$ it clearly indicated that even though the first amendment applies in full force in special settings, its protections "must always be applied in light of the special characteristics of the ... environment' in the particular case." 102 On the basis of this principle, the Court suggested that advocacy of noncriminal acts which could not generally be proscribed-such as advocacy of violation of certain campus rules-could be proscribed on the campus. ${ }^{103}$ Justice Rehnquist, who concurred in the result, was unhappy with this attempt to pay homage to Brandenburg while ignoring its lesson, and he candidly discussed the issues that had remained submerged in both Healy and the bar admission cases. He seriously doubted whether cases dealing with the imposition of criminal sanctions, such as Brandenburg, should be applied in special settings and he thought the government as employer or school administrator could impose "reasonable regulations" upon employees and students that would be impermissible if imposed on society in general:

[T]here can be a constitutional distinction between the infliction of criminal punishment, on the one hand, and the imposition of milder administrative or disciplinary sanctions, on the

police acted unconstitutionally in ordering the students to disperse because the rally did not present "a clear and present danger of imminent violence." 9 Cal. $3 \mathrm{~d}$ at 623,510 P.2d at 1024, 108 Cal. Rptr. at 472 . The court stated that noise may be made criminal "only when there is a clear and present danger of violence or when the communication is not intended as such but is merely a guise to disturb persons." 9 Cal. $3 \mathrm{~d}$ at 619,510 P.2d at 1021,108 Cal. Rptr. at 469 . In so stating, the Califormia Supreme Court went beyond not only Healy but also Grayned v. City of Rockford, 408 U.S. 104 (1972), wherein the United States Supreme Court held, 8-1, that a municipal ordinance declaring that "no person, while on public or private grounds adjacent to any building in which a school or any class thereof is in session, shall willfully make or assist in the making of any noise or diversion which disturbs or tends to disturb the peace or good order of such school session or class thereof . . . " Id. at 107-08, was facially constitutional.

Thus the Supreme Court of California has applied Brandenburg literally to both campus and bar admission cases, as the United States Supreme Court has not. See note 84 supra.

101 The Court unnecessarily obscured its analysis of the speech issue in Healy by its insistence that "the critical line for First Amendment purposes must be drawn between advocacy, which is entitled to full protection, and action, which is not." 408 U.S. at 192. This statement either ignores the category of "unprotected advocacy," or else classifies it as action. But the fact remains that not all advocacy of action is unprotected under Brandenburg.

102408 U.S. at 180, quoting Tinker v. Des Moines Ind. Community School Dist., 393 U.S. 503, 506 (1969).

is See text at note 91 supra. 
other, even though the same First Amendment interest is implicated by each. ${ }^{104}$

These words encapsulate the issues underlying the bar admission cases and Healy. ${ }^{105}$ One view running through the opinions is that advocacy can be restricted in the context of special institutions in ways that would be impermissible in society at large; and further, that the relevant speech test may be more speech-restrictive when only noncriminal sanctions may be imposed. The other view assumes that a citizen retains his or her rights undiluted when entering the role of attorney or student; since denial of bar admission or exclusion from campus deter speech as effectively as criminal penalties, the same speech test should apply when these sanctions are imposed as in a criminal trial. The difficulty with the first view is that, because its proponents (except for Justice Rehnquist) have not admitted that they are applying a test less stringent than Brandenburg, they have not had to set forth their reasons for doing so. Thus Justice Stewart did not explain why he looked to Scales rather than to Brandenburg in Wadmond, and Justice Powell, whose opinion in Healy may have sanctioned the relaxation of Brandenburg's imminence requirement in the campus context, was

104408 U.S. at 202-03 (Rehnquist, J., concurring).

105 Cf. Papish v. Board of Curators of the Univ. of Mo., 410 U.S. 667 (1973) (per curiam), where the debate over whether speech tests are less stringent on campus and over the effect of imposition of noncriminal sanctions continued, this time in the context of obscenity. In Papish a graduate student was expelled from a state college for distributing a publication which, although concededly not obscene under prior Court decisions, was nonetheless offensive. The majority, reversing the district and circuit courts' denial of relief, relied on Healy to hold that the same standard of obscenity must apply on campus as in the world at large:

[In Healy], while recognizing a state university's undoubted prerogative to enforce reasonable rules governing student conduct, we reaffirmed that "state colleges and universities are not enclaves immune from the sweep of the First Amendment" [citations omitted]. We think Healy makes it clear that the mere dissemination of ideas-no matter how offensive to good taste-on a state university campus may not be shut off in the name alone of "conventions of decency." . . . Since the First Amendment leaves no room for the operation of a dual standard in the academic community with respect to the content of speech, and because the state University's action here cannot be justified as a nondiscriminatory application of reasonable rules governing conduct, the judgments of the courts below must be reversed.

Id. at 669-71. Chief Justice Burger and Justices Rehnquist and Blackmun dissented on the ground that even if distribution of the publication to the general public could not be criminally punished, distribution on campus could result in expulsion. They emphasized the difference in sanctions. See id. at 671-72 (Burger, C.J., dissenting); id. at 676-77 (Rehnquist, J., dissenting). They also emphasized the need to ensure a campus

environment [where] students may learn the self-restraint necessary to the functioning of a civilized society and understand the need for those external restraints to which we must all submit if group existence is to be tolerable.

Id. at 672 (Burger, C.J., dissenting). 
unclear about the interests which he thought it was necessary to protect. Even Justice Rehnquist fails to offer substantial justification for the "reasonable regulations" that he would impose upon student speech "that would be impermissible if imposed by the government upon all citizens." Deciding cases on the basis of unarticulated premises can only lead to doctrinal uncertainty.

3. Levy and Whitcomb-Denial and Reaffirmance. The issues of institutional exceptions and noncriminal sanctions which Justice Rehnquist brought into the open in Healy have been central to the resolution of two Supreme Court advocacy cases since then. ${ }^{106}$ In one, Parker v. Levy, ${ }^{107}$ the Court returned to its Wadmond tactic of simply ignoring Brandenburg, although it did make a gesture in the direction of candor by specifying the institutional needs that it

${ }_{106}$ The Court also examined special institutional needs in resolving the first amendment issues in Procunier v. Martinez, 416 U.S. 396 (1974), where it affirmed a district court's decision holding that a prison rule imposing censorship on inmates' incoming and outgoing mail was unconstitutional. The rule defined as contraband:

Any writings or voice recordings expressing inflammatory political, racial, religious or other views or beliefs when not in the immediate possession of the originator, or when the originator's possession is used to subvert prison discipline by display or circulation [and any writings] not defined as contraband under this rule, but which, if circulated among other immates, would in the judgment of the warden or superintendent tend to subvert prison order or discipline....

Id. at 399 n.3. The rules also banned correspondence which "unduly complain[ed] or "magniflied] grievances." Id. at 399 n.2. The Court avoided the question of the "extent to which an individual's right to free speech survives incarceration," id. at 408 , instead basing its holding on the first amendment rights of prisoners' outside correspondents. Justice Powell, writing for the Court, cited Tinker and Healy as cases where "the Court undertook careful analysis of the legitimate requirements of orderly school administration in order to ensure that the students were afforded maximum freedom of speech consistent with those requirements," $i d$. at 410 , finding those cases "generally analogous to our present inquiry." Id. at 412. Identifying as specialized prison needs "the preservation of internal order and discipline, the maintenance of institutional security against escape or unauthorized entry, and the rehabilitation of the prisoners," id. (footnote omitted), Justice Powell found the rules overbroad, holding that a valid censorship rule must further "one or more of the substantial governmental interests of security, order, and rehabilitation" and that "the limitation of First Amendment freedoms must be no greater than is necessary or essential to the protection of the particular governmental interest involved." Id. at 413. That Justice Powell did not envision application of Brandenburg here is suggested by his failure to cite that case and by his statement:

[A]ppellants defend the ban against "inflammatory political, racial, or religious or other views" on the ground that "[s] uch matter clearly presents a danger to prison security. ..."

The regulation, however, is not narrowly drawn to reach only material that might be thought to encourage violence nor is its application limited to incoming letters.

Id. at 416. See also Pell v. Procunier, 417 U.S. 817 (1974), where the Court followed the same sort of analysis in upholding prison rules against press interviews with prisoners over both prisoners' and newsmen's first amendment arguments.

${ }^{107} 417$ U.S. 733 (1974). 
believed it was protecting. In the other, Communist Party of Indiana $v$. Whitcomb, ${ }^{108}$ the Court explicitly reaffirmed Brandenburg, rejecting arguments that a lesser standard of advocacy was appropriate in light of the institutional needs and civil nature of the sanctions involved.

In Levy the Court affirmed the conviction by court-martial of defendant Levy, an Army physician stationed at Fort Jackson, South Carolina, under article 133 of the Uniform Code of Military Justice, which proscribes "conduct unbecoming an officer and a gentleman," and article 134, which proscribes "all disorders and neglects to the prejudice of good order and discipline in the armed forces." Levy had stated to enlisted personnel at the post:

The United States is wrong in being involved in the Viet Nam War. I would refuse to go to Viet Nam if ordered to do so. I don't see why any colored soldier would go to Viet Nam: They should refuse to go to Viet Nam and if sent should refuse to fight because they are discriminated against . . . in the United States, and ... in Viet Nam .... [I]f I were a colored soldier and were sent I would refuse to fight. Special Forces personnel are liars and thieves and killers of peasants and murderers of women and children. ${ }^{100}$

Justice Rehnquist, writing for the Court, first reviewed at length the general differences between the military and civilian communities and between their systems of law. ${ }^{110} \mathrm{He}$ then held that

108414 U.S. 441 (1974).

109417 U.S. at 736-37. The specification against Levy under article 134 charged that defendant "did ... with design to promote disloyalty and disaffection among the troops, publicly utter [certain] statements to divers enlisted personnel at divers times . . . " Id. at 738. The specification under article 133 charged that defendant "did 'while in the performance of his duties . . . wrongfully and dishonorably' make statements variously described as intemperate, defamatory, provoking, disloyal, contemptuous and disrespectful to Special Forces personnel and to enlisted personnel who were patients or under his supervision." Id. at 739. It is unclear from the specifications whether Levy made the statements only to personnel under his command or treatment in the course of those duties, or whether some of the statements were also made to others on the base in nonduty hours. Compare id. at 738 n.5, with id. at 739 n.6.

Levy was sentenced to dismissal from service, forfeiture of all pay and allowances, and confinement for three years at hard labor. Id. at 736.

${ }^{110}$ Id. at 743-52. Echoing his emphases in Healy, Justice Rehnquist stated that "the Uniform Code of Military Justice regulates a far broader range of the conduct of military personnel than a typical state criminal code regulates of the conduct of civilians; but at the same time the enforcement of that Code in the area of minor offenses is often by sanctions which are more akin to administrative or civil sanctions than civilian criminal ones.

"The availability of these lesser sanctions is not surprising in view of the different relationship of the Government to members of the military. It is not only that of law giver to citizen, but also that of employer to employee." Id. at 750-51. 
articles 133 and 134 are not unconstitutionally vague because military authorities had construed them "in such a manner as to at least partially narrow [their] otherwise broad scope"; 111 because the rule of Smith $v$. Goguen, ${ }^{112}$ that a vague statute which touches protected expression is to be scrutinized carefully, should not be applied to military rules; ${ }^{113}$ and because in any event defendant's conduct was clearly within the articles' proscription: "One to whose conduct a statute clearly applies may not challenge it for vagueness."114

Justice Rehnquist then turned to Levy's argument that the articles, although they covered a range of constitutionally punishable conduct, were overbroad and hence invalid because they also covered protected speech. The Justice's reasoning in support of his rejection of the overbreadth argument was in two steps. First, he said, the first amendment doctrine that one who challenges a statute as overbroad on its face need not "demonstrate that his own conduct could not be regulated by a statute drawn with the requisite narrow specificity" 115 must "be accorded a good deal less weight in the military context." "116 Second, defendant's own speech was "unprotected under the most expansive notions of the First Amendment." 117 Hence, although "there may lurk at the fringes of the Articles . . . some possibility that conduct which would be ultimately held to be protected by the First Amendment could be included within their prohibition,"118 defendant was not in a position to make the overbreadth claim.

The bulk of Justice Rehnquist's exposition is, on its face, directed to explaining why the quasi-standing rule of the overbreadth doctrine is accorded less weight in the military context. Thus, he said:

While the members of the military are not excluded from the protection granted by the First Amendment, the different character of the military community and of the military mission require a different application of those protections. The fundamental necessity of obedience . . . may render permissible within the military that which would be constitutionally im-

\footnotetext{
iII Id. at 752.

112415 U.S. 566 (1974).

is 417 U.S. at 755-56.

III Id. at 756.

11s Id. at 759, quoting Dombrowski v. Pfister, 380 U.S. 479 (1965).

i1 417 U.S. at 760.

i17 Id. at 761.

118 Id. at 760-61.
} 
permissible outside it. Doctrines of First Amendment overbreadth . . . are not exempt from the operation of these principles. ${ }^{119}$

But this observation cannot by itself explain Justice Rehnquist's further conclusion, reached without apparent difficulty, that Levy's particular speech was unprotected by the first amendment. Even conceding what Justice Rehnquist assumed, that Levy's statements were incitement to disobedience of orders rather than a mere statement of belief, ${ }^{120}$ there was no evidence that Brandenburg had been satisfied, that his remarks had constituted incitement to imminent disobedience, or that such action was likely to be produced.

Although Justice Rehnquist never directly addressed this point, as he did in his concurrence in Healy, he evidently was aware that Brandenburg was in fact not being followed. ${ }^{121}$ He noted that even revolutionary advocacy is tolerable in the civilian community within the limits of Brandenburg, because it does not directly affect the capacity of the government to discharge its responsibilities. But, he went on, in the military, protection of advocacy must be viewed differently because the armed forces depend on a command structure that at times must commit men to combat, thereby placing both individual lives and national security in jeopardy. Thus, he said, "[s]peech that is protected in the civil population may nonetheless undermine the effectiveness of response to command. If it does, it is constitutionally unprotected." 122

It is difficult to imagine a more vague version of the "danger" test than the one enunciated by Justice Rehnquist. Speech critical of any aspect of the military, or of its Commander-in-Chief, might

i1 Id. at 758.

${ }^{120}$ Justice Rehnquist characterized the defendant's statements as "urging Negro enlisted men not to go to Vietnam if ordered to do so," $i d$. at 757, and "publicly urging enlisted personnel to refuse to obey orders which might send them into combat." Id. at 761.

Compare Justice Douglas's characterization:

[Defendant] was uttering his own belief-an article of faith that he sincerely held. This was no mere ploy to perform a "subversive" act. Many others who loved their country shared his views. . . . Uttering one's beliefs is sacrosanct under the First Amendment.

Id. at 772 (Douglas, J., dissenting).

121 Although Levy inexplicably did not cite Brandenburg, he argued that the courtmartial did not find a "clear and present danger" of anything, citing inter alia Schenck v. United States, 249 U.S. 47 (1919). See Brief for Appellee on Motion to Dismiss or Affirm at 18-19, Parker v. Levy, 417 U.S. 733 (1974); Brief for Appellee at 40-44, Parker v. Levy, 417 U.S. 733 (1974). The test of advocacy employed by the presiding officer at the court-martial was whether defendant's statements had a "clear and reasonable tendency to promote disloyalty and disaffection." Brief for Appellee on Motion to Dismiss or Affirm at 18, Parker v. Levy, 417 U.S. 733 (1974), quoting Record, vol. 9, at 2594.

122417 U.S. at 759, quoting 21 U.S.C.M.A. at 570, 45 C.M.R. at 44. 
be thought to "undermine the effectiveness of response to command" or to have a tendency to promote disobedience. Indeed, the potential breadth of this doctrine was exposed a year after Levy was decided when the Court, on the authority of Levy, affirmed the court-martial of a soldier who, during night duty in a combat zone in Vietnam, typed a statement in which he suggested that the United States should withdraw from Vietnam. ${ }^{123}$ After he asked a military mimeograph operator to make copies of the statement, he was charged with and convicted of "an attempt to publish a statement disloyal to the United States and to members of the Armed Forces 'with design to promote disloyalty and disaffection among the troops." "124

The result in Levy is, however, perhaps not totally indefensible; Levy, it could be argued, violated a reasonable regulation of the time and place of his expression or, in the alternative, addressed his remarks to a captive audience in derogation of his duty. ${ }^{125}$ But Levy could have been punished under Justice Rehnquist's rationale if he had delivered the same speech to the same group off-base during offduty hours, ${ }^{126}$ even though Brandenburg would protect a civilian speaker in those circumstances. ${ }^{127}$ The point is that one may agree

123 Secretary of the Navy v. Avrech, 418 U.S. 676 (1974). The gist of the statement for which Avrech was court-martialed was that:

The United States has no business over here. This is a conflict between two different politically minded groups. . . . Do we dare express our feelings and opinions with the threat of a court-martial perpetually hanging over our heads? Are your opinions worth a court-martial? We must strive for peace and if not peace then a complete U.S. withdrawal.

Brief of Appellee at 2-3, Secretary of the Navy v. Avrech, 418 U.S. 676 (1974).

12 418 U.S. at 676-77. Much of Avrech's argument was directed against article 134 on vagueness grounds, but he also argued that his speech was constitutionally protected under Brandenburg. Brief of Appellee at 63-71. The district court held against him on this claim, which the court of appeals found unnecessary to decide because it held for him on the vagueness claim. 477 F.2d 1237, 1239 (D.C. Cir. 1973). Justice Douglas would have decided the advocacy claim in his favor. 418 U.S. at 679-80 (Douglas, J., dissenting). Justices Marshall and Brennan, although agreeing that Levy controlled the vagueness claim, would have remanded to the court of appeals for consideration of the first amendment claim. Id. at 68182 (Marshall, J., dissenting). On remand, the court of appeals denied Aurech's first amendment claim. 520 F.2d 100 (D.C. Cir. 1975). The Court also relied on Levy in Schlesinger v. Councilman, $95 \mathrm{~S}$. Ct. 1300 (1975), where it held that a serviceman was subject to courtmartial rather than trial in a civilian court for allegedly selling, transferring and possessing marijuana at his off-base apartment in Oklahoma while off-duty and in civilian clothes.

12 That is, if Levy's statements were only made to persons under his control during the time he was supposed to be training or treating them. See note 109 supra.

12 Cf. Schlesinger v. Councilman, 95 S.Ct. 1300 (1975), note 124 supra.

127 See Kiiskila v. Nichols, 433 F.2d 745 (7th Cir. 1970) (en banc). There the Seventh Circuit, relying on Brandenburg, overturned the order of the commanding officer of the Fort Sheridan Military Reservation barring from the post a civilian employed there because she distributed leaflets off the post for a forthcoming antiwar rally in Chicago. See also Carlson v. Schlesinger, 511 F.2d 1327, 1343 (D.C. Cir. 1975) (Bazelon, C.J., dissenting). 
with Justice Rehnquist's premise that obedience of orders is a legitimate institutional need of the military and that the military may punish disobedience of orders, without following him to the conclusion that the military must also have the power to punish speech that merely has a tendency to produce disobedience. Since military personnel often come in contact with potentially subversive civilian speech and literature that is protected under Brandenburg, the Court's failure to explain its justification for deleting the imminence requirement in judging the speech of military speakers is particularly disappointing. In the absence of such a justification, it is difficult to understand why the Court could not have applied the Brandenburg concept fully without impairing the military's valid interests by relying on those institutional interests to give content to the term "lawless action" but then still protecting all speech that does not imminently incite this expanded notion of lawlessness.

In contrast to the Court's amorphous treatment of advocacy in Levy is Communist Party of Indiana v. Whitcomb. ${ }^{128}$ In Whitcomb the Communist Party was excluded from the Indiana ballot for refusing to take an oath that it did not "advocate the overthrow of local, state or national government by force or violence."129 Justice Brennan, writing for the Court, ${ }^{130}$ looked to Brandenburg as the applicable test of advocacy. He held that the oath was overbroad because it failed to distinguish between protected and unprotected advocacy and the state could therefore not use it as a condition for access to the ballot.

In reaching this decision, Justice Brennan rejected the theory that a standard less demanding than Brandenburg applied where noncriminal sanctions were imposed. He observed that the Brandenburg guarantee had often been applied in noncriminal contexts, and saw no reason for refusing to apply it here. "[B]urdening access to the ballot, . . ." he wrote, "is to infringe interests certainly

123414 U.S. 441 (1974).

12 Id. at 442-43. The Party had submitted an affidavit to that effect to which it added the qualifying statement:

The term advocate as used herein has the meaning given it by the Supreme Court of the United States in Yates $v$. United States [citation omitted], "the advocacy and teaching of concrete action for the forcible overthrow of the government, and not of principles divorced from action."

Id. at 444. The Indiana Election Board rejected the affidavit in this form.

${ }_{130}$ Chief Justice Burger, joined by Justices Powell, Blackmun and Rehnquist, concurred only in the result, finding it unnecessary to reach the first amendment issue because the Election Board had discriminated against the Party by requiring only it, and not the Republican or Democratic parties, to submit the affidavit in question. 414 U.S. at 451 (Powell, J., concurring) (relying on Williams v. Rhodes, 393 U.S. 23 (1968)). 
as substantial as those in public employment, tax exemption, or the practice of law."131 The Court also considered the State's suggestion that Brandenburg was inapplicable because of the unusually grave danger to the electoral process posed by participation by advocates of violent overthrow. ${ }^{132}$ This contention was also rejected, Justice Brennan noting that to rule otherwise would revive the "thoroughly discredited" regime of Whitney $v$. California, unanimously overruled by the Court in Brandenburg. ${ }^{133}$ Thus Whitcomb stands as a reaffirmance of Brandenburg, a forceful reply to Justice Rehnquist's suggestion in Healy that Brandenburg ought not apply where noncriminal sanctions are involved, and a rejection of the notion that the vulnerability of government to subversion from within requires loosening the test of advocacy.

\section{B. Proposed Resolution of the Debate}

As this examination of the bar admission cases, Healy, Levy, and Whitcomb is intended to suggest, a majority of the Court seems to have been groping for a way to protect what it perceives to be special institutional needs while retaining both Brandenburg as the
131414 U.S. at 448-50.
132 The state had argued that:
It is fraudulent for a group seeking by violent revolution to overthrow our democratic form of government to disguise itself as a political party and use the very forms of the democracy it seeks to subvert in order to gain support and carry on its nefarious ends. Brief of Appellees at 7, quoted in 414 U.S. at 450.

13514 U.S. at 450 (footnote omitted). The footnote at the end of this passage is a curious "cf." citation to Noto v. United States, 367 U.S. 290 (1961), a companion case to Scales. The footnote describes Noto as a case "where we held that the constititional limitations require that criminal advocacy by the Communist Party be proved by 'some substantial direct or circumstantial evidence of a call to violence now or in the future' . . ." $414 \mathrm{U} . \mathrm{S}$. at $450 \mathrm{n} .8$ (emphasis added), quoting 367 U.S. at 298. As has been noted already, though, the "now or in the future" language in Noto was implicitly overruled in Brandenburg. See text and notes at notes 77-78 supra. Here, as in other cases, the Court's pretense in Brandenburg that it was merely following Dennis and Yates obscures the holdings of Brandenburg and Hess. See text and notes at notes 31-33 supra.

It is interesting to note in this connection the holding in Orians v. James, 84 Wash. 2d 819,529 P.2d 1063 (1974) (en banc). The court there struck down a loyalty oath required of political candidates which was similar to the one in Whitcomb, stating:

Our statute is broadly stated and extracts an oath denying mere advocacy or knowing membership in an organization engaging in such mere advocacy. These are the very standards which the Whitcomb decision struck down. To be constitutional, the oath statute must be narrowly drawn so as to be limited to advocacy directed to inciting or producing imminent lawless action which is likely to incite or produce such action. Our statute is not so drawn.

84 Wash. 2d at 821-22, 529 P.2d at 1065 (emphasis added). Thus the Supreme Court of Washington, like that of California, see notes 84 \& 100 supra, has read Brandenburg as the test of advocacy in situations where the Supreme Court has equivocated. 
test for unlawful advocacy and the traditional rule that the level of protection accorded speech is not dependent on the character of the sanction imposed. The approach taken in the Wadmond and Levy opinions, however, is both disingenuous and dangerous. Because the majorities in those cases adopted the expedient of ignoring Brandenburg altogether, they were not confined by the discipline of distinguishing disconcerting precedent. Had they recognized Brandenburg, they would have had to pinpoint the institutional interests requiring special protection against advocacy and the reasons why those interests could not be adequately protected without abandoning Brandenburg's imminence requirement. In short, had they recognized Brandenburg, they would have had to explain why they did not follow it.

The danger in the Wadmond-Levy approach is that institutional exceptions could all too quickly swallow the Brandenburg rule. All institutions have goals and needs which, it can be argued, differentiate them from the world at large. If the logic of Wadmond and Levy is that such goals and needs, once perceived however dimly, may always be protected from speech that may tend to endanger or undermine them, then a good portion of the first amendment rights of a member of such an institution will be stripped away. Given the current pervasive contacts between the institutions of government and the populace, it might turn out that Brandenburg itself is the exception.

Although Justice Powell's opinion in Healy is not a model of thoroughness in specifying the special goals and needs that might require modifying Brandenburg in some way in the campus context, it offers an attractive alternative to Wadmond and Levy for accomodating the protection of such goals and needs to Brandenburg. Justice Powell, it will be recalled, wrote that in the campus context the Brandenburg notion of "lawless action" might be extended beyond criminal acts to include violation of campus rules designed to protect important campus goals and needs. The idea is that, just as society at large has laws defining socially harmful and therefore punishable conduct, institutions must be able to define and protect themselves from institutionally harmful conduct. Under Brandenburg and Hess, advocacy of "societal" lawlessness is outside the first amendment only if it constitutes incitement to imminent lawlessness, and is likely to produce imminent lawlessness. Justice Powell's Healy opinion, which cites Brandenburg, can be read to suggest that the same reasoning applies to incitement of violation of institutional rules; advocacy of "institutional" lawlessness is unprotected only if it is incitement to imminent lawlessness, and is likely to produce it. 
Justice Powell's approach carries with it both promise and dangers. The promise is that under his approach, attention must focus on particular institutional rules and, more importantly, the particular needs they are thought to serve. An institutional rule, violation of which would fit into Brandenburg's "lawless action" category, would have to protect a weighty institutional need-there is no justification for diminishing a person's constitutional rights in the service of an insubstantial special interest. Similarly, one would not wish to punish incitement to imminent littering in the world at large; such a de minimis notion has always run through the advocacy cases, and critical examination of the purpose of the underlying legal norm has always played a part in judging advocacy. ${ }^{134}$ Finally, since much, if not all, of the conduct which would seriously threaten an institution like a college would be punishable under criminal law as well as campus rule, an institutional rule proscribing noncriminal conduct should be closely examined before incitement of its violation is made punishable.

The promise of Justice Powell's approach can be lost, however, if a court does not rigorously protect advocacy of all but imminent lawlessness. The requirement of imminence is the heart of the Brandenburg test. If, as has been argued, Brandenburg limits Dennis and Yates, so that advocacy of what was assumed to be the ultimate danger to society-violent overthrow of the government-cannot be punished unless the speaker advocates imminent

134 The de minimis notion was strong in Chief Justice Vinson's opinion in Dennis, where the seriousness of the harm feared was one of the factors to be weighed:

[M] any of the cases in which this Court has reversed convictions by use of [the clear and present danger] or similar tests have been based on the fact that the interest which the State was attempting to protect was itself too insubstantial to warrant restriction of speech. . . . Overthrow of the Government by force and violence is certainly a substantial enough interest for the Government to limit speech. Indeed, this is the ultimate value of any society, for if a society cannot protect its very structure from armed internal attack, it must follow that no subordinate value can be protected.

Dennis v. United States, 341 U.S. 494, 508-09 (1951) (Vinson, C.J.). Justice Brandeis had expressed much the same thought in Whitney:

[E]ven imminent danger cannot justify resort to prohibition of [speech and assembly], unless the evil apprehended is relatively serious. Prohibition of free speech and assembly is a measure so stringent that it would be inappropriate as the means for averting a relatively trivial harm to society. . . . [I]t is hardly conceivable that this Court would hold constitutional a statute which punished as a felony the mere voluntary assembly with a society formed to teach that pedestrians had the moral right to cross unenclosed, unposted waste lands and to advocate their doing so, even if there was imminent danger that advocacy would lead to a trespass. The fact that speech is likely to result in some violence or in destruction of property is not enough to justify its suppression. There must be the probability of serious injury to the State.

Whitney v. California, 274 U.S. 357, 377-78 (1927) (Brandeis, J., concurring). 
overthrow and is likely to produce action to accomplish that unlawful end, then advocacy of lesser dangers-such as the disruption of a student council meeting-should not be punishable on a lesser standard.

This conclusion is supported by recalling that the speech test announced in Brandenburg is not absolute. It does not shield all speech from government interference, as many have thought the first amendment requires. Under Brandenburg the courts draw a line, not between speech and action, but between mere advocacy and advocacy that incites to imminent lawless acts. Professor Kalven considered that Brandenburg delimited the "minimal jurisdiction over political speech that concern with public order requires be ceded." 135 That limit should be maintained where the state punishes by noncriminal sanctions, and in special situations like schools and the Armed Forces as well as on street corners. A flexible conception of "lawlessness" gives a court whatever tools it needs to calibrate the degree of danger in special situations. The "imminence" requirement should be rigidly respected. Brandenburg $v$. Ohio should be a test for all seasons.

\section{ConcLusion}

In Brandenburg $v$. Ohio, the Supreme Court laid down a new test defining when the state may forbid or proscribe political advocacy. Under Brandenburg the state may forbid or proscribe advocacy of unlawful action only when it (a) advocates imminent lawless action, and (b) is likely to produce imminent lawless action. In recent years, the Court has applied the Brandenburg test literally in cases where criminal convictions were sought under statutes regulating the speech activity of the population at large, but has not done so in certain arguably special institutional settings where speech has been restricted by noncriminal sanctions-instead ignoring Brandenburg's imminence requirement. The Supreme Court's performance in the early 1970 s, a period when domestic tension has been less than in 1914-1918, or 1948-1954, does not inspire confidence in how the Court would protect speech in a time of renewed crisis, Brandenburg notwithstanding. The widening ink blot of exceptions could all too easily be extended to include speech "when a nation is at war," 136 and speech in the context of an organized conspiracy to overthrow the government. The "thoroughly discredited"

135 See note 55 supra.

is Schenck v. United States, 249 U.S. 47, 52 (1919). 
regime of Whitney $v$. California would thus be reinstated.

The alternative recommended here is to allow the courts to look to special institutional interests in giving content to the notion of "lawless action" in the Brandenburg formula. But once lawless action has been defined in its relevant institutional setting, the courts should then apply the Brandenburg speech test in full whenever the state forbids or proscribes advocacy. Imminence should retain its central importance. In this way, the valid interests of government's important institutions can be protected without sacrificing the individual's fundamental constitutional right to free speech.

Staughton Lynd 